\title{
DNA Vaccines Approach: From Concepts to Applications
}

\author{
Vanessa Bastos Pereira1*, Meritxell Zurita-Turk1*, Tessália Diniz Luerce Saraiva1, \\ Camila Prósperi De Castro1, Bianca Mendes Souza1, Pamela Mancha Agresti1, \\ Fernanda Alvarenga Lima', Vanessa Nathalie Pfeiffer ${ }^{1}$, \\ Marcela Santiago Pacheco Azevedoㅁ, Clarissa Santos Rocha ${ }^{1}$, Daniela Santos Pontes ${ }^{2}$, \\ Vasco Azevedo ${ }^{1}$, Anderson Miyoshi ${ }^{1 \#}$ \\ ${ }^{1}$ Laboratório de Genética Celular e Molecular, Instituto de Ciências Biológicas, Universidade Federal de Minas \\ Gerais (UFMG), Belo Horizonte, Brazil \\ ${ }^{2}$ Universidade Estadual da Paraíba (UEPB), João Pessoa, Brazil \\ Email: ${ }^{\#}$ miyoshi@icb.ufmg.br
}

Received 25 February 2014; revised 25 March 2014; accepted 2 April 2014

Copyright (C) 2014 by authors and Scientific Research Publishing Inc.

This work is licensed under the Creative Commons Attribution International License (CC BY). http://creativecommons.org/licenses/by/4.0/

(c) (i) Open Access

\begin{abstract}
DNA vaccines are the third generation vaccines based on purified plasmid preparations containing transgenes that encode antigenic/therapeutic proteins or peptides capable of triggering an immune response against a wide range of diseases. This vaccine platform presents several attributes that confer distinct advantages over other vaccine technologies in terms of safety, ease of fabrication and stability. Many aspects, such as antigen expression and especially vector design, are under study because of their great influence on immunogenicity and efficacy of DNA vaccines. In this regard, with the attempt of improving the efficiency of DNA vaccines, co-expression of stimulatory sequences and diverse vector delivery systems are being optimized. With this in mind, this review aims to giving a conceptual approach of DNA vaccines, explaining their mechanisms of action and listing the already licensed veterinary DNA vaccines presented in the market.
\end{abstract}

\section{Keywords}

DNA Vaccines, Vector Design, Delivery Systems, Approved DNA Vaccines, Bacterial Delivery

\section{Introduction}

According to World Health Organization (WHO) estimates, 18 million people die each year as a direct conse"These authors contributed equally to this work.

"Corresponding author. 
quence of infection, showing that these diseases still remain a considerable burden worldwide for which no effective treatment or vaccine exists [1]. Furthermore, we can also add the problems related to inefficient drug therapies and increase microbial resistance to antimicrobials and antibiotics treatments [2] [3]. Moreover, new pathogens and "old" infectious diseases which have been thought to be extinct have emerged over the last two decades, highlighting the importance of developing new vaccines against infectious agents over the last century [4].

Vaccination represents one of the most cost-efficient tools to combat and eradicate diverse pathogenic and/or infectious agents spread around the world. Several infectious diseases, such as polio, measles, diphtheria, rubella, mumps and tetanus can be controlled and, in many cases, be eradicated with current vaccines as these have been used to mimic natural infections activating an immune response and consequently an immune protection without any potential harmful effects to patients.

There exist different types of vaccines in clinical use. Currently, all licensed vaccines are based on killed or live-attenuated microorganisms, purified products derived from microorganisms, such as inactivated toxins, purified antigens or polysaccharides conjugated to proteins which are able to efficiently induce humoral (antibody) and/or cellular immune responses essential to prevent and control diseases of global importance (Table 1). However, it is well known that some of these vaccines may cause harmful side effects or health risks in a sensitive part of the population and some can even present several disadvantages, including expensive costs, limited coverage, weak induction of cell-mediated immune responses, limited storage conditions and the inadequacy of the use of needles for some vaccine administration [5]. Moreover, vaccines for many pathogens, such as the human immunodeficiency virus and the agents of malaria and tuberculosis are until now ineffective or unavailable [6], being the lacky of vaccines to prevent or treat these complex diseases one of the major public health problems in the world.

Several factors still limit the effectiveness of vaccination, which must be overcomed with the advances in the biotechnology field and a deeper comprehension of the immune system. In this regard, an ideal vaccine should include the following characteristics: 1) safe profile for the entire population; 2) long-term immunity and efficacy; 3) single dose administration; 4) easy administration through mucosal routes; 5) simple manufacturing; 6) resistance to temperature changes; 7) multivalency and 8) disease control [7]. In this regard, a new generation of vaccines is being developed to overcome technological limitations and to achieve safety and desirable requirements to prevent and/or treat diseases [7].

The era of genomics, proteomics, transcriptomics and metabolomics opens a new perspective for the development of new vaccines, playing an important role in the identification of potential antigens and drug targets, and in a better understanding of pathogens and their interactions with the host immune system. Moreover, the nature and the persistence of the immune response are very important points to be analyzed in new vaccination strategies. And, recently, several approaches, such as DNA vaccines, have been developed to improve vaccine safety and efficacy using sophisticated biological technologies.

Perspectives for new and potential vaccines and therapeutic biotechnology emerged in 1950 when Stasney and colleagues showed that the features responsible for cancer malignancy were present in the chromatin of tumor cells and could be transferred to normal cells [8]. Following, several researchers demonstrated that plasmids harboring a desired gene sequence could be delivered into eukaryotic cells to target protein expression [9]-[11] and in 1992 Tang and colleagues showed that injection of plasmids containing the genomic copy of the human growth hormone $(\mathrm{hGH})$ gene was capable of eliciting a specific humoral immune reaction against the hormone,

Table 1. Overview of the current vaccine platforms (Adapted from [60]).

\begin{tabular}{ccccc}
\hline Vaccine Types & Characteristics & Immune Aspects & Main Disadvantages \\
\hline Attenuated Vaccines & Replicative live vaccine & TCD8+ cells activation & Potencial reversion of pathogenicity \\
Inactivated Vaccines & Inactive vaccines & B cells activation & Poor induction of T-cell response \\
Subunit Vaccines & Antigens from pathogens & TCD8+ and B cells activation & Immunogen preparation \\
Toxoid & Inactivated toxin & B cells activation & Transitory effect \\
Vectored Vaccines & Recombinant live vaccine & TCD8+ and B cells activation & Potencial of adverse effects \\
DNA Vaccine & Recombinant plasmid & TCD8+ and B cells activation & Less efficient induction \\
expres antibody response
\end{tabular}


suggesting that DNA could also be used to induce specific immune responses against infectious diseases [12]. Soon after, in 1993, two different research groups demonstrated that immunization with a DNA plasmid could protect mice against a lethal influenza challenge [13] [14]. Since then, great interest in developing DNA vaccines, mainly due to their ability to elicit both humoral and cellular immune responses as well as protecting and even having therapeutic benefits in a variety of animal models for a wide range of disease targets, has emerged.

DNA vaccines are the third generation vaccines that have been developed in order to overcome undesired properties of current conventional vaccines, since they can stimulate concomitantly different types of immune responses, improve vaccine stability and facilitate large-scale manufacturing. Diverse studies have already shown the potential of these new generation vaccines in preventing various infectious diseases in preclinical animal models and, also, their applications in immunotherapy to treat different types of cancer, allergies and autoimmune diseases [15].

Great progress has been made in the field of DNA vaccination and many works have shown good results, proving that DNA vaccines are able to induce efficient immune responses in animals using genes from a variety of infectious agents, including influenza virus, hepatitis B virus, human immunodeficiency virus, human papilloma virus and Mycobacterium tuberculosis. However, each DNA vaccine has to be well evaluated considering its applicability, the nature of the agent being immunized against, the nature of the antigen and the type of immune response required for protection. Until now, only four DNA vaccines [16]-[20] have been licensed for veterinary use. Despite the success of these DNA vaccines and the positive results of others in clinical trials, the efficiency of DNA vaccines in primates and humans is still lower than most researchers had anticipated [21]. Nevertheless, it is generally believed that the advances in DNA vaccine technology will offer customized and tailored vaccines to any disease in the future, representing an important component of next generation of prophylactic and therapeutic vaccines, efficient and economically accessible to peoples worldwide.

\section{Elements of DNA Vaccine Vector Design}

Several approaches have been leading the way to develop innovative, efficient, safe and promising vaccine modalities for humans and animals in the last years. Bacterial derived plasmid vectors are used in DNA-based vaccination to express molecules of medical and veterinary interest. These plasmids must internalize eukaryotic cells and reach their nucleus, where DNA transcription and translation of the gene of interest is driven by the cells. To achieve an efficient plasmid delivery into eukaryotic cells it is important to design and engineer plasmids that allow maximum transfection efficiency and protein expression.

DNA plasmids used for vaccination are based on constructed bacterial-derived plasmids that contain a eukaryotic gene expression cassette, responsible to code the immunogenic or immunomodulatory molecule of interest in mammalian cells, and thus, allowing their in vivo generation. DNA vaccine plasmids can be divided into two main structures: 1) the plasmid backbone, necessary for prokaryotic propagation and which contains a bacterial origin of replication and a bacterial selectable marker like an antibiotic resistance gene, and 2) a transcriptional unit, required for eukaryotic expression, which includes the promoter, used to drive optimal and high expression of the ORF (open reading frame) of interest in mammalian cells, and the Polyadenylation (poly A) sequence. Besides these two main structures it is also necessary to insert in the ORF of interest a specific consensus sequence present in the eukaryotic mRNA, called Kozak sequence (ACCATGG), which signals the start codon and is necessary to initiate protein synthesis in eukaryotic cells. To ensure correct translation termination and prevent read through, it is also important to add stop-codons in the ORF (Figure 1).

The replication region of the plasmid backbone allows the maintenance and propagation of the plasmid in host cells for stable inheritance of the plasmid during bacterial growth, as well as to determine the plasmid's host-range [22]. Nowadays, most of the plasmids used for this purpose derive from the pBR322 or pUC plasmids. It is preferred to use origins of replication that provide large copy DNA plasmids in bacteria with high purification yields in a short period of time, such as the Escherichia coli (E. coli): Co1EI origin of replication [23].

Selectable markers, like bacterial antibiotic resistance genes, ensure stable plasmid inheritance during bacterial growth and kanamycin is one of the most widely used today [24]. Although antibiotic resistance genes represent powerful selectors, their use is discouraged by regulatory authorities due to concerns regarding plasmid transformation, alteration of microorganisms-associated characteristics of the patients and the spread of antibiotic resistance genes throughout the host's body [22]. Although antibiotic selection systems are important and convenient for cloning steps, these are undesirable within a DNA vaccine plasmid. Considering this issue, anti- 


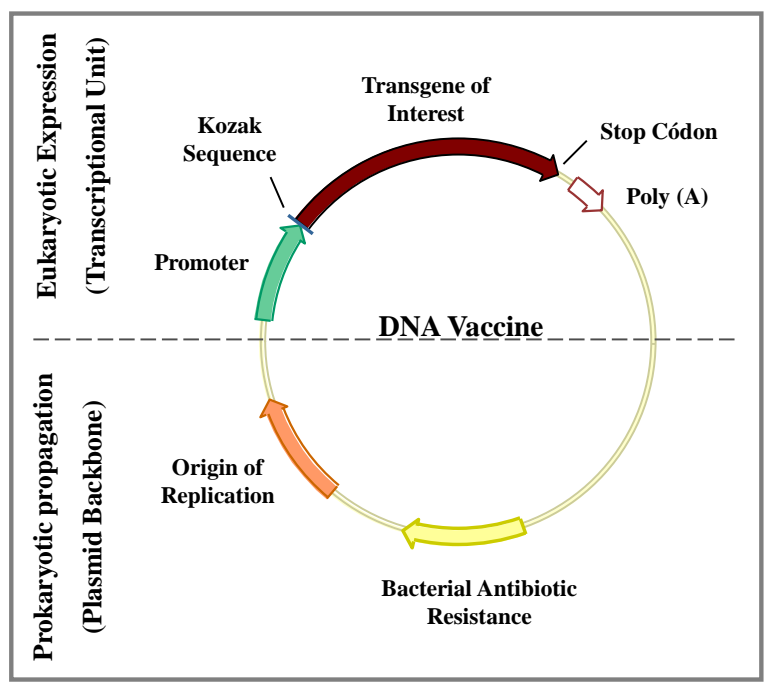

Figure 1. Structure of DNA vaccine plasmids. The top of the figure shows the transcriptional unit (eukaryotic expression region), responsible for high-level expression of the antigen of interest in eukaryotic cells, containing the promoter, the transgene of interest with the Kozak sequence, stop codon and polyadenylation sequence (poly A). The lower part of the figure (prokaryotic region) is responsible for propagation and vaccine plasmid maintenance in bacterial cells, containing a prokaryotic replication origin and a selectable marker (Adapted from [143]).

biotic free selection systems have to be developed by implementation of combined approaches [25] [26].

Promoters are required in plasmids to drive optimal and high expression of the gene of interest in mammalian cells. In general, virally-derived promoters, such as the cytomegalovirus (CMV) and the simian virus 40 (SV40) promoters are used for such purpose as these provide greater gene expression in vivo compared to other eukaryotic promoters [27]. Currently, the CMV promoter drives high constitutive transgene expression levels and is the strongest and most widely used promoter in traditional DNA vaccines formulations [28]. However, alternatives to viral promoters are under investigation and include non-viral promoters of which the major histocompatibility complex class II (MHC-II) promoter is the most representative [29].

The insertion of the specific consensus sequence called Kozak sequence (ACCATGG) is necessary to initiate protein synthesis in eukaryotic cells. To prevent incorrect translation in the cell and which could lead to oversized and incorrect product folding and interfere with mRNA stability, it is also important to add one or two stop-codon sequences [30].

On the other hand, poly A sequence signal (AAUAAA) inclusion next to the 3' extremity of the sequence of interest is essential for efficient transcriptional termination and exportation of the mRNA from the nucleus to the cytoplasm, playing also a very important role in mRNA stability and eukaryotic expression. The Bovine Growth Hormone (BGH) polyadenylation signal is widely and efficiently used to achieve high level of expression peptides in eukaryotic cells [31].

\section{Advantages of DNA Vaccines}

DNA vaccines have a wide range of attributes that confer them distinct advantages over other vaccine technologies in terms of safety, ease of fabrication, stability and immunogenicity (Table 2).

Opposite to traditional vaccines developed against pathogens, which include either killed or attenuated pathogenic agents, DNA vaccines do not involve unsafe infectious agents, present no risk of pathogenicity and can be safely administered to anyone. Furthermore, DNA vaccines can efficiently activate the three arms of adaptive immunity - antibodies, helper $T$ cells $\left(T_{h}\right)$ and cytotoxic T-lymphocytes (CTLs) - as well as innate immune responses [32]. 
Table 2. Advantages/Characteristics of DNA vaccines (Adapted from [144]).

\begin{tabular}{cll}
\hline Advantages & & \multicolumn{1}{c}{ Characteristics } \\
\hline Immunogenicity & - Induction of T and B cell-specific antigen \\
Safety & - Inability to revert to virulent forms \\
& - No efficacy does not depends on toxic treatments \\
Construction & - Oodifications in the transgene construct and vaccine can be made in short time \\
Stability & - Increased thermal stability-Long life time \\
Mobility & - Easy storage and transport-No need for constant refrigeration \\
Time manufacturing & - Rapid production and formulation \\
\hline
\end{tabular}

Due to their highly flexible genetic design and simple structure, DNA plasmids can be easily manipulated and modified in a short period of time, a critical attribute when producing vaccines against emerging pandemic threats. Cheap and large-scale production of DNA vaccines is possible since DNA plasmid vaccine vectors can be easily replicated and amplified in bacteria. Another important advantage is that DNA vaccines are highly stable at room temperature and easily stored, as they do not require special refrigeration, making them very practical for use in developing nations [33].

Moreover, DNA vaccines are highly flexible and able to code multiple proteins in a single construct, including viral or bacterial antigens and immunological and biological proteins, creating multigenes or multivalent vaccines with the possibility of adjuvant addition to enhance their potency [23] [34]. It is also worth mentioning that DNA vaccines can be used therapeutically [35], as they are unable to induce auto-immunity and have theoretically unlimited boosting potential, which could be very useful in areas of cancer vaccine development which require repetitive boosting of $\mathrm{T}$ cell responses to combat tumor antigens.

Despite the clear advantages DNA vaccines present, it is important to take into consideration some safety concerns associated to the possibility of DNA plasmid integration into the host's cell genome, development of auto-immunity, as well as resistance of the antibiotic gene markers that should be addressed in appropriate animal tests and human trials. However, DNA vaccines already tested did not present relevant integration into the genome of host cells [36]-[39] and no convincing evidences for the development of an auto-immune responses against DNA vaccines exist in pre-clinical studies performed in non-human primates and in humans [40]-[42].

\section{Mechanism of Action and Immunology of Prophylactic DNA Vaccines}

The main purpose of prophylactic vaccination is to prime both humoral and cellular immune responses against specific antigens. It appears that innate responses that augment the adaptive response may also be crucial. In this context, DNA vaccines represent a potential strategy to reach the desirable immune responses to raise immunity protection against diseases. The capacity of genetic immunization to induce immune responses was firstly documented in 1992 by Tang et al., who demonstrated that mice inoculated with micro projectiles coated with plasmid DNA harboring the human growth hormone (hGH) sequence were able to produce a specific anti-hGH immune response [12]. This result opened new perspectives for the development of DNA vaccine delivery systems and several approaches have shown since then the potential and efficacy of this new technology to induce immune responses.

The general mechanism of action of DNA vaccines consists of in vivo DNA plasmid inoculation and expression of the gene of interest by host cells. Once the DNA plasmid is administrated and internalized by the cells, the plasmid uses a net of microtubules and their associated motor proteins in the cytoplasm to reach the cellular nucleus [43]. Following, transcription and translation of the transgene occurs via the host's cellular machinery and the produced proteins are then presented to the surface of cells to become a target of the immune system. In contrast, when DNA vaccines are administrated for therapeutic purposes, the produced proteins must be secreted outside the cells to stimulate the immune system and generate both humoral and cellular immune responses. Several studies have demonstrated the importance of direct transfection of antigen-presenting cells (APCs) and 
their critical role in DNA vaccine immunogenicity. Dendritic cells (DCs) are probably the most important APCs associated with the capture and processing of antigens via receptor-mediated endocytosis and its presentation to MHC class I and II. CD4+ and CD8+ lymphocytes can be activated during the process of DNA vaccination, inducing cellular immune and specific antibodies responses [44] [45].

DNA vaccines for prophylactic or therapeutic uses can be administered via different routes: intradermal, intravenous, intraperitoneal, subcutaneous and intramuscular [46] [47]. The intramuscular route is one of the most common and successful routes of immunization used in DNA vaccine studies both for prophylaxis or immunotherapy. Parenterally administered vaccines are more effective against pathogens that enter the body through systemic routes but are less effective in stimulating the immune system associated with mucous membranes, a non-invasive delivery route.

\section{Mucosal DNA Vaccines}

The respiratory, gastrointestinal and urogenital tracts are covered by mucosal surfaces, represent the main portal of entry of pathogens and are protected by a large and highly specialized innate and adaptive mucosal immune system. As the majority of infections affect or start at mucosal surfaces, eliciting a mucosal immune response can prevent the infectious agents from attaching and colonizing the mucosal epithelium (non-invasive bacteria), or from penetrating and replicating in the mucosa (viruses and invasive bacteria) and/or block microbial toxins to bind to and affect epithelial and other target cells [48].

The preferred mucosal routes for vaccination purposes are the vaginal [49], intranasal [50] and oral mucosas [51]. However, potent adjuvants are required to augment the effects of plasmid vaccines in humans, especially if these are delivered in small amounts, as is the case of intranasal delivery [50].

Initial infections are prevented through the action of secretory IgA (S-IgA) antibodies, the receptor-mediated endocytotic activity and antigen presentation by phagocytic cells [52]; protection after infection is based on activation of CD8+ and CD4+ T lymphocytes, which are the major effect or cells of the mucosal immune system [52]. In this regard, many vaccines have already focused on improving the mucosal delivery systems to elicit both effective systemic cellular and humoral immune responses [53] [54].

Sites of the gut-associated lymphoid tissue (GALT), such as Peyer's patches (PPs) and isolated lymphoid follicles in draining gut mesenteric lymph nodes (MLNs), are more accessible to antigens and bacteria present in the luminal compartment than other sites of the mucosa. Moreover, specialized antigen sampling cells, such as M cells in the GALT, are capable of taking up particulate antigens and specific binding proteins by endocytosis and transport them to the underlying immune cells. DCs residing in the subepithelial dome region of the lymphoid follicles are then activated by contact with microbial antigens and migrate to the GALT, where they prime T cell responses [55].

Lymphocytes involved in intestinal immune responses are found in organized immune inductive sites of the GALT [56], where the largest number is concentrated in B- and T-cell zones. B-cell zones contain germinal centers believed to be the sites of isotype switching to IgA production and affinity maturation while T-cell zones contain large numbers of APCs such as DCs and macrophages [57] [58].

On the other hand, PP facilitate induction of mucosal immunity, with antigen stimulated B- and T-cells able to migrate to the systemic blood supply via the lymph to be seeded back to mucosal sites around the body [58] [59]. This enables communication between mucosal surfaces of the body [57].

The efficacy of DNA vaccines delivery by $\mathrm{M}$ cells depends on whether the administered agents can survive the gastric and intestinal environments, including $\mathrm{pH}$-induced degradation, enzymes and diffusion across the mucus layers, and whether residence time in the intestine is long enough for sufficient interaction with target cells so that these can endocytose the vaccines. Therefore, oral administration of vaccines often requires delivery systems that can provide protection against enzymatic degradation and elimination in the gastrointestinal tract in order to maintain high bioavailability [60]. However, results of experimental approaches have proven difficult to induce strong intestinal immune responses as a single and naked oral administration of a DNA vaccine is usually not enough to achieve an immune response; development of effective mucosal delivery systems remains an active area of research.

Biological parameters that characterize a DNA vaccine's effectiveness have already been elucidated, although the exact mechanisms by which DNA vaccines produce antigen-specific immunity in vivo still require further studies. In addition, in many human clinical trials, the immune response has not been as effective as that seen in 
non-human models and strategies to improve the immune response to plasmid DNA vaccines are under study [61].

\section{How to Improve Immunogenicity of DNA Vaccines?}

The vaccination process of DNA vaccines is directly related to their ability to induce protective immunity, considering that the induction of strong cellular and humoral immune responses is essential in eukaryotes. Many aspects, such as antigen expression and especially vector design, have great influence in the immunogenicity and efficacy of DNA vaccines and should be taken into consideration. In this regard, in an attempt to improve DNA vaccines, optimization of the following tools should be addressed: 1) plasmid DNA vectors, 2) transgene sequence, 3) co-expression of stimulatory sequences, 4) vector delivery system, and 5) targeting of the vector for appropriate immune stimulation.

\subsection{Codon Usage}

One of the problems to reach optimal levels of expression of the foreign genes of interest by DNA vaccine expression vectors in mammalian cells is the notable differences that are found among the codon usage of different pathogenic organisms and mammals. As such, codon optimization could be an efficient alternative to enhance the expression and immunogenicity of the transgene in mammalian cells, suiting the sequence to host codon bias based on generally available transfer RNA (tRNA) levels without altering the original amino acid sequence of the protein. It has been experimentally documented that common codons increase the translational rates of the expressed target gene compared with the use of rare codons, and the relative frequency of use of each codon depends and varies between species [62] [63].

Several approaches using the strategy of codon usage optimization have been successful in increasing protein translation rates and inducing efficient immune responses. Optimization of codon usage in mice influences the effects of DNA vaccines, enhancing translation efficiency and effective immune responses against intracellular bacteria such as Listeria monocytogenes and Mycobacterium tuberculosis [64]. Pulsawat and coworkers showed that codon optimization of Dermatophagoides pteronyssinus group 1 allergen improved its expression in vitro and induced an allergen-specific Th1 response in mice, representing a promising hypoallergenic DNA vaccine candidate for immunotherapy against house dust mite allergy [65].

Messenger RNA (mRNA) optimization is also an essential step for achieving larger expression of the sequence of interest. Besides, the large number of C-G rich sequences in the mRNA translation of the protein can be inhibited as an increase in the formation of secondary structures and the presence of pre-mRNA processing sites are capable of causing aberrant expression of the sequence of interest [66].

\subsection{Customization of Antigenic Sequence}

Candidate genes for a DNA vaccine construction for prophylactic uses are usually molecules associated with pathogenicity and/or virulence of infectious agents that are commonly modified to target proteins to different cellular locations, cytoplasm, cell wall or extracellular medium, since the expression of proteins in different compartments can influence the immunological response. Moreover, targeting antigens of interest to proteasomes or endosomes, using ubiquitin fusions, can also increase the number of peptides available to ligate to the major histocompatibility complex of class I (MCH-I) when induction of CTLs is required. Often, when it is necessary to express more than one gene of interest to trigger a protective immune response, polycistronic expression systems or even molten epitopes expressed as a unique polypeptide can be used [27].

\subsection{CpG Motifs}

Immune stimulatory sequences, called unmethylated phosphodiester linked cytosine and guanine (CpG) motifs, act through the Toll-like receptor 9 (TLR-9) to induce a series of immune stimulatory cytokines that lead to the activation of B-cells, monocytes, macrophages, dendritic cells (DCs) and natural killer (NK) cells, enhancing both non-specific and antigen-specific responses [67]. Cells are able to discriminate between endogenous and exogenous DNA based on these motifs, being these sequences practically absent in human cells, presenting, thus, adjuvant properties in DNA vaccines [68]. 


\subsection{Untranslated Regions (UTRs)}

UTRs are also responsible for regulating genetic expression through elements placed at the 5' and 3' ends of the translating sequence. Enhancer elements (boosters) and trans-activators of transcription can increase the activity of the promoter when placed at the 5' or 3' end of the gene. Some studied trans-activators have viral origin, such as the regulatory regions that act as transcriptional and post-transcriptional boosters [69]. So, the addition of leader sequences or 5'-UTR before the gene sequence can increase the stability of mRNA and contribute to larger translation efficiency.

\subsection{Adjuvants}

It has been demonstrated that co-injection of immune modulatory plasmids constitutes a promising strategy to improve the efficiency of DNA vaccines. These plasmids code for cytokines, such as interleukins, interferons, stimulatory colony factors and tumoralnecrose factors, chemokines and costimulatory molecules, with the objective of increasing the quantity and potential of APCs without the adverse effects of cytokine administration in the form of purified proteins. Tests performed in monkeys with a DNA vaccine in development against HIV-1 demonstrated that co-administration of a plasmid codifying IL-12 and IL-15 increased the cellular and humoral immunity [70].

Another way to increase the immunogenicity of vaccines could include the use of mixed vaccines, where the first dose would have a specific formulation and the second dose, the booster, a different one [71]. Prime-boost vaccines, including DNA, can elicit immune responses that differ in magnitude, quality and balance of cellular and humoral responses from those elicited by single components and could thus provide further enhancement for DNA immunizations. It has already been reported that this prime-boost strategy increases the production of antibodies [46] [72]. This strategy has been widely applied in a large number of vaccines, including HIV [73]-[75], avian influenza virus [76], tuberculosis [71] [77] [78] and malaria [79], resulting in stronger immune responses.

\subsection{Nuclear Targeting Sequences}

DNA nuclear targeting sequences (DTS) are recognition sequences of endogenous DNA-binding proteins that are essential for the transport of proteins into the cell's nucleus. Considering this, optimizing the vector design by introducing DTS in the plasmid DNA can lead to an increased expression of the sequence of interest. It has been verified that specific virus sequences, such as that of the Simian Virus 40 (SV40), are capable of driving the bacterial plasmid to the nuclear compartment increasing the levels of gene expression, both in vitro [80]-[82] and in vivo [32] [83] [84]. The DTS of SV40 has 372 base pairs and contains ligation sites for several transcription factors that present nuclear localization signals and can transport the protein-plasmid complex through the nuclear pores using the nuclear import machinery of the host cell [80]. Moreover, there are also evidences of other existing sequences that act as DTS. Mesika and colleagues showed a 12-fold expression increase of the luciferase reporter protein when using plasmids in which repeated sequences of binding sites for the transcription factor NF-kB were cloned [85]. Other groups demonstrated that when the oriP sequences from the Epstein-Barr virus or copies of the tet operator (tetO) were inserted into plasmids, these increased the nuclear import and expression of the reporter genes carried by them [86] [87].

\section{DNA Delivery Systems}

DNA vaccines can be administered by different systems and routes. The delivery of DNA molecules into mammalian cells is a valuable tool to take into account when designing a DNA vaccine. The potential of transfection methods is essential to modulate gene expression and efficient induction of immunological responses, and several different DNA delivery systems have been evaluated and explored to improve their transfection capacity and induction of immunological responses, mainly to humans and large animals. The efficiency of these delivery systems depends on several factors, such as cell type, cellular context (in vitro, in vivo, ex vivo), transgene capacity and general safety.

It is essential that the gene delivery system does not present harmful side effects to the hosts. Currently, several different approaches are being used for gene delivery, being the approaches based on viral vectors or nonviral methods the most commonly used. While viral vectors remain the most common approach, non-viral approaches have become more popular, as the use of viral vectors can raise safety concerns, such as toxicity and 
possible induction of strong immunogenic reaction; as such, other non-viral strategies have become an alternative. Non-viral methods include chemical, physical and biological methods that can deliver the DNA directly to the host cell cytoplasm (Table 3).

\subsection{Virus Delivery Systems}

It has become clear that there can be no single vector that is suitable for all applications. Viruses are simple and capable to infect host cells using the cell's machinery to express the gene of interest and produce the antigen in its native form. Virus-based vectors harness the viral infection pathway but avoid the subsequent expression of viral genes that leads to replication and toxicity. Furthermore, these vectors can carry and express multiple antigens. An efficient viral vector has to be able to induce the multiple arms of the immune system and present safety issues.

At present, five main classes of clinically applicable viral vectors are derived from oncoretroviruses, lentiviruses, adenoviruses, adeno-associated viruses (AAVs) and herpes simplex-1 viruses (HSV-1s). Each of these classes is characterized by a set of different properties that make it suitable for some applications and unsuitable for others. The only characteristic required by all vectors are the abilities to be reproducibly and stably propagated and purified to high titres, to mediate targeted delivery and to mediate gene delivery and transgene expression without inducing harmful side effects. The five main classes of viral vector can be categorized in two groups according to whether their genomes integrate into host cellular chromatin (oncoretroviruses and lentiviruses) or persist in the cell nucleus, predominantly as extra-chromosomal episomes (AAVs, adenoviruses and herpes virus). Due to safety concerns, the replication-defective viruses are most utilized in clinical trials. Although viral vectors have been widely used, their principal inconvenience is that they may cause genetic diseases or favor the development of cancerous cells. Moreover, severe adverse effects were observed during two independent gene therapy trials, raising serious safety concerns about the use of viral vectors [88] [89].

The virus classes most widely used for gene therapy applications in clinical trials are Oncoretrovirus vectors. A limitation to the usefulness of C-type retrovirus vectors is that they can only gain access to the cell nucleus if the nuclear membrane breaks down; therefore, they can only transduce dividing cells. Lentivirus vectors on the other hand can naturally penetrate an intact nuclear membrane and transduce non-dividing cells. These vectors have proven to be effective tools for gene delivery to the central nervous system, generating long-term gene expression in the absence of inflammation [90]. Adenovirus vectors are the most efficient class of vector in terms of delivery to the cell nucleus and due to recent improvements that reduce the immunogenicity they have enhanced their prospects for long-term gene transfer in a wide range of different tissues. However, production of

Table 3. Main DNA vaccine delivery systems.

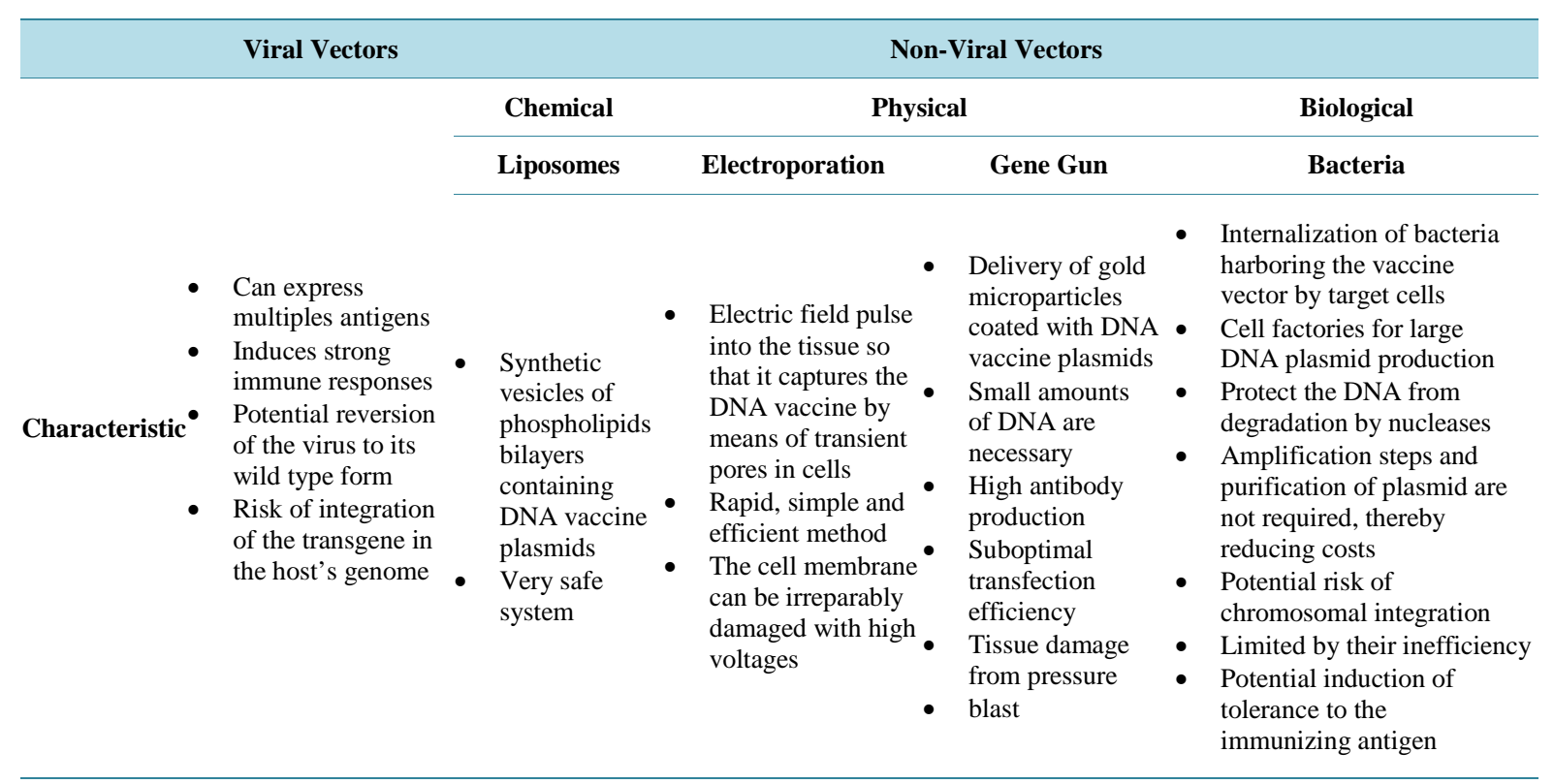


these viruses is very laborious. Regarding safe long-term gene transfer and expression in non-proliferating tissues, recombinant AAV vectors are the most promising vector system. The small size and simplicity of the vector particle makes it possible to administer high doses of vector systemically without eliciting acute inflammatory responses or toxic side effects. In contrast, HSV-1 is the largest virus and has therefore the capacity to carry large fragments of foreign DNA [89]. However, major limitations of these vectors are their cytopathic effect and the induction of an immune response by viral gene expression [91].

Several viral vectors have already been evaluated for their capability as immunization systems in human clinical trials. The replication-defective recombinant adenovirus serotype 5 (rAd5) vector was used as a HIV-1 vaccine candidate and showed to induce antigen-specific $\mathrm{T}$ cell responses while showing its safety and immunogenicity [92] [93]. A recombinant baculovirus bearing human endogenous retrovirus (HERV) envelope protein used as a carrier for a human papillomavirus (HPV-16L1) DNA vaccine (AcHERV-HP16L1) was developed and results in mice showed that this viral delivery system is more advantageous than Gardasil, the current prophylactic vaccine commercialized against HPV, showing higher cellular immunogenicity, considerably lower production cost and comparable safety [94].

Overall, viral vectors represent one of the most efficient vehicles for gene transfer into most tissues; however, these systems have important disadvantages that include the induction of innate immune responses, possible reversion to the wild type form of the virus, risk of integration of the transgene into the host's genome and human preexisting immunity against viral vectors. Several obstacles still have to be overcome and approaches are still on their way to find the standards for an ideal viral delivery system that will include the targeting of specific populations of cells in a target tissue and expressing therapeutic levels of transgene expression in a safe and regulated manner for the appropriate length of time.

\subsection{Non-Viral Delivery Systems}

\subsubsection{Naked DNA Delivery}

Naked DNA plasmid transfection is a simple and direct method, free of complex formulations or from agents, to transfer in vivo DNA gene sequences of interest. Several naked DNA vaccines have already been tested for some diseases: herpes simplex virus type 1, leishmaniosis, malaria, HIV and different types of cancer. However, to achieve significant levels of immunity in humans and large animals, DNA delivery methods often require very high doses of plasmids and multiple boosts [42] [95] [96]; thus, increasing the efficiency of DNA vaccines in humans is still required.

Animals immunized intranasally with a combination of DNA plasmids of a multiclade/multigene HIV-1 formulated with a lipid adjuvant showed significantly higher IgA levels in fecal pellets, while an enhancement of IgG systemic responses were observed both when the DNA was delivered mucosally and into the muscle. Animals immunized with plasmid DNA alone (naked) did not develop measurable vaccine specific systemic IgG responses and very low or no mucosal humoral responses [50].

Another study to understand the details of DNA vaccine delivery in vivo used naked plasmid or polymer/DNA complexes injected intradermally into mice. When analyzing the transgene expression (luciferase) and the local tissue distribution of the plasmid DNA, comparable number of luciferase expressing cells were observed in the skin of mice that had received the naked plasmid or polyplexes one day after transfection; however, naked plasmid levels dropped below detection limit after $24 \mathrm{~h}$, whereas polyplexes persisted for up to 2 weeks, revealing that naked plasmid disperse quickly in the skin of mice after injection [97]. This emphasizes the importance of using a potent delivery system and an effective formulation for efficient plasmid immunization.

Insufficient cell membrane permeability and low cellular uptake of DNA plasmid vectors contribute for a decreased protein expression and consequently for a reduction of DNA vaccine effectiveness. Toxicity and non-efficient delivery systems also represent an obstacle for DNA vaccine development. Therefore, alternative potent transfection methods must be improved and developed [49]. The potential of genetic immunization is obvious and the efficiency of the DNA delivery method to reach the target tissue is highly important for the success of clinical trials. Naked DNA vaccines still require an improvement in their delivery to boost better immune responses and protect against diseases.

\subsubsection{Physical Delivery Approaches}

Physical approaches are the simplest ways to transfer DNA into a cell as they use a physical force to permeate 
the cell membrane and allow intracellular gene transfer. However, physical approaches have to consider two important factors for the development of DNA delivery systems: the entry of DNA of interest in the target cells and its transport through the plasma membrane. Physical delivery methods show several advantages over other, such as the requirement of small amounts of DNA, direct bombardment of the DNA into cells, high transfection efficiency, high immunogenicity and high antibody production.

From out these approaches we can highlight gene gun, which is a ballistic needle free DNA delivery method that promotes cellular transfection by the bombardment of gold micro particles coated with specific DNA vaccine plasmids. Gene gun was originally developed for plant tissue transfections, but it also showed to be efficient to transfect animal and human cells and to induce cellular and humoral immunity in murine [98]-[100] and human hosts [101]. Nevertheless, gene gun also presents the drawbacks of suboptimal transfection conditions and possible tissue damage from pressure blast [102] [103].

Electroporation represents another physical delivery method and which is an electrically mediated injection technique that induces the permeabilization of the plasma membrane creating pores and allowing the introduction of plasmids containing foreign genes into the cells, which will subsequently express the desired genes. The reclosing of the cell membrane occurs naturally; however, the cell membrane can irreparably be damaged when high voltages are applied [104] [105]. Electroporation is a rapid, simple and efficient method widely used for the delivery of DNA, membrane protein insertion and other macromolecules into various types of cells, with numerous applications in the medical field and conventional biological laboratories [105]. Various complex extraand intra-cellular factors can affect cell viability, such as the intracellular solute concentration, the electrical charge and the neighboring cells. Current studies have focused on the improvement of DNA molecules transport across the plasma membrane of the cell to optimize electrically mediated gene delivery [106].

\subsubsection{Chemical Delivery Approaches}

Chemical approaches use synthetic or naturally occurring compounds as carriers for gene delivery. These systems seem to be very safe and quite efficient. The most studied strategy uses cationic polymers and cationic lipids which transfers the DNA to the cells through intracellular vesicles, from which a small fraction of the DNA is released into the cytoplasm and migrates into the nucleus, where the transgene expression occurs.

Liposomes are synthetic vesicles consisting of phospholipid bilayers and represent one of the major techniques used for gene delivery into cells nowadays. A large number of cationic lipids with different molar ratios, such as derivate of diacylglycerol, lipids, polyamines and cholesterol, make the generation of different kinds of liposomes, possessing different physicochemical characteristics like size and net surface charge, possible [107]. Upon mixing with cationic liposomes, plasmid DNA is condensed into lipoplexes that trigger cellular uptake and facilitate the release of DNA from intracellular vesicles. The transfection efficiency of lipoplexes is affected by a great number of factors that include the chemical structure of the cationic lipid, the charge ratio between the cationic lipid and the DNA, the total amount of lipoplexes applied and the cell type.

Different types and configurations of cationic polymers have been explored and are widely used as carriers for both in vitro and in vivo gene delivery. An example of a commonly used cationic polymer for gene delivery is Polyethylenimine (PEI) [108], which requires condensation of the DNA with cationic polymers and the formation of PEI/DNA complexes [109]. This PEI/DNA complex is then taken up by the cell into acidified endosomal compartments and released into the cytoplasm where it finally reaches the nucleus [110] [111]. Different molecular sizes, commonly 800kDa (PEI800) and 22kDa (PEI22), or structures, linear or branched, of PEI have already been described. A study showed that this variability could have a direct effect on the transfection efficiency both in vitro and in vivo. The use of this polymer for DNA delivery in DNA-based immunotherapy or vaccination shows protective action by eliciting strong immune response [112]-[114].

\subsubsection{Biological Approaches: Bacteria as DNA Vaccine Delivery System}

Development of effective strategies for the delivery of DNA vaccines to mucosal tissues has received considerable attention over the past decade, as well as the use of recombinant bacteria as carrier systems. Live recombinant bacteria and attenuated bacterial pathogens appear to be attractive and promising vehicles for vaccine delivery and to induce both humoral and cellular immune responses [115].

Several bacterial species are capable of transferring vaccine plasmids to mammalian host cells and are considered cell factories that can produce large amounts of DNA plasmids. In 1980, Walter Schaffner observed, for the first time, gene transfer from bacteria to mammalian cells when tandem copies of the SV40 virus genome, 
carried by E. coli laboratory strains, were transferred into co-cultured mammalian cells [116].

Bacterial DNA vaccine delivery systems consist in the internalization of bacteria, harboring a plasmid vector containing the sequence of the gene of interest, by target cells. Subsequent primary vesicle are formed and then fused to lysosomal compartments where lysis of bacteria occurs, releasing the plasmid DNA into the host's cytosol. The plasmid DNA then migrates to the nucleus of the cell where the gene sequence of interest is transcribed for subsequent transduction and protein synthesis by the host's cells machinery [117] [118].

The use of bacteria as vehicles for the delivery of DNA vaccines has several advantages when compared to other methods, such as naked DNA vaccination and viral carriers. Bacteria deliver DNA vaccine plasmids directly into the interior of the cells protecting the DNA from degradation by nucleases. Moreover, bacterial vehicles also act as natural antigens after host cell invasion, due to the presence of molecular markers associated to pathogens (PAMPs) that are capable of modulating the innate immune response and promote a robust and lasting adaptive response [119].

Bacterial carrier strains are easy to manufacture and allow for the maintenance of plasmids with high cloning capacity. Stable replication of vaccine plasmids by different bacterial carrier species can be further ensured by introducing bacterial genes, essential for survival or virulence within the host, into the vaccine plasmids and, thereby, circumventing the need to co-administrate plasmid selection markers [120]. Furthermore, in contrast to immunization with naked plasmid DNA or other delivery methods, no further plasmid amplification and purification steps are required, reducing thereby costs and labor extensively. Moreover, most bacterial carriers allow for mucosal immunization via oral route, show natural tropism for inductive sites of the immune system and provide danger signals which lead to a more efficient activation of the immune system as compared to immunization by naked DNA [118].

Currently, the most widely used bacteria for DNA delivery are intracellular attenuated pathogenic bacteria, such as Salmonella typhi, Listeria monocytogenes, Shigellaflexneri, Yersinia enterocolitica and E. coli [118]. In 1999, Fenelly and colleagues reported that an attenuated strain of S. flexneri carrying a DNA plasmid vaccine encoding different antigens of measles virus was able to induce, in intranasally immunized mice, a strong $\mathrm{T}_{\mathrm{h}} 1$ type response and a lower amplitude $\mathrm{T}_{\mathrm{h}} 2$-type response [121]. Shata and Hone demonstrated that attenuated $S$. flexneri carrying a vaccine plasmid encoding the HIV-1 protein gp120 showed significant protection in mice against a challenge with a recombinant vaccinia virus-env vector, after intranasal vaccination [122]. Woo et al. (2001) and Zheng et al. (2001) evaluated, in a mouse model, the feasibility of Salmonella typhimurium delivering a plasmid-encoded HBV surface antigen at eliciting effective cellular immune responses. They concluded that the relatively absent humoral but strong cellular response could make this vaccine a potential therapeutic vaccine candidate for chronic HBV [123] [124].

In another work, a recombinant attenuated $L$. monocytogenes strain carrying plasmids for eukaryotic expression of the Mycobacterium tuberculosis Ag85 complex (Ag85A and Ag85B) and MPB/MPT51 molecules, showed the induction of specific protective cellular immunity against $M$. tuberculosis. A specific $T_{h} 1$ cellular immune response following protective cellular immunity against an intravenous challenge with $M$. tuberculosis H37Rv, comparable to that caused by the conventional live BCG vaccine strain, was also observed [125].

However, these attenuated pathogenic bacteria present potential risk of reversion to their wild-type (virulent) phenotype, associated risk of infection and sensitive public opinion about their use as not being completely safe for human use, especially in children and immune compromised patients. Moreover, variation in the immunogenicity of the different attenuated strains has constituted a major problem and it has been difficult to reach the right balance between the level of attenuation (i.e., lack of disease symptoms) and immunogenicity (i.e., efficacy) [126].

In this regard, the use of non-pathogenic and food-grade bacteria, such as lactic acid bacteria (LAB), can represent an attractive alternative as vehicles for mucosal DNA delivery vaccines, since they are naturally present in foods and have long been consumed by humans, can be safely delivered at high doses and generate mucosal and systemic immune responses [127] [128].

Lactococcus lactis as DNA vaccines

Lactococcus lactis, the model LAB, has been widely used as vehicle for the delivery of exogenous antigens at mucosal level [127]. L. lactis is one of the most advanced prototypes of non-invasive, non-colonizing bacterial vaccine vehicles. Presenting the "GRAS" (Generally Recognized As Safe) status, L. lactis can be orally and intranasally administered, do not need further plasmid amplification neither purification steps [129], and some species of this group are capable of increasing the amount of IgA in the mucosa and stimulate the phagocytic 
system of the host [54]. Moreover, LAB have little immunogenic activity and can be continuously used in immunization programs, do not present lipopolysaccharides (LPS) on their cellular wall, eliminating all possible risks of shock by endotoxin, and can be easily engineered to express multiple proteins and other molecules [127].

The use of L. lactis as microbial host for DNA delivery into mammalian cells has been evaluated as another promising DNA vaccination strategy [115] [130]-[132]. Delivery of DNA into mammalian cells was demonstrated by Guimarães and colleagues in 2006 using native L. lactis strains capable of delivering a plasmid (pLIG: BLG1) harboring the bovine $\beta$-lactoglobulin (BLG) gene, one of the major cow's milk allergen, under the transcriptional control of the viral promoter CMV. Production and secretion of BLG was observed in Caco-2 cells after incubation with $L$. lactis carrying the DNA plasmid vector, demonstrating that $L$. lactis is able to deliver BLG cDNA into mammalian epithelial cells in vitro [129]. After that, Chatel et al. showed that this L. lactis strain (pLIG:BLG1) orally administered to mice was also able to transfer the functional plasmid vector to mice's epithelial membranes of the small intestine and induce a low and transitory $\mathrm{T}_{\mathrm{h}} 1$-type immune response [51].

In an approach to improve DNA vaccine delivery, wall weakening treatments in L. lactis, with glycine, penicillin or lysozyme, were used to promote the uptake of these bacteria by Caco-2 cells. Strains harboring a functional plasmid containing a reporter red fluorescent protein (RFP) gene were used in vitro for gene delivery and L. lactis strain NZ3900 treated with glycine showed a good gene transfer frequency. However, a mechanism by which treated bacteria could be efficiently internalized into Caco-2 cells has not yet been developed and could be an interesting strategy to avoid the use of virulent genes [131].

In another attempt to improve DNA delivery, an invasive L. lactis strain expressing internalin A (InlA), a cell wall-anchored protein and major invasin of Listeria monocytogenes, was constructed [133] [134]. InlA binds to an extracellular domain of E-cadherin, a transmembrane cell-to-cell adhesion molecule. It was demonstrated that this recombinant $L$. lactis could be successfully internalized by epithelial Caco-2 cells in vitro and by enterocytes in vivo after oral administration in guinea pigs. In addition, L. lactis InlA+ was able to deliver a vaccine vector expressing the green fluorescent protein (GFP) under the control of the CMV promoter and about $1 \%$ of Caco-2 cells expressed eGFP after co-culture with this strain [135]. However, it is important to note that in vivo experimental studies with $L$. lactis expressing the IntA+ are limited to guinea pigs or transgenic mice expressing human E-cadherin, as InlA only binds to human E-cadherin and does not interact with murine E-cadherin, limiting its experimental use in mouse models [136].

Thus, in the attempt of improving DNA delivery and increasing its use for a wider range of animal models, a new recombinant invasive $L$. lactis strain expressing the Fibronectin-Binding Protein A (FnBPA) of Staphyloccocusaureus [137] was constructed [136]. FnBPA mediates adhesion to host tissue and bacterial uptake into phagocytic and non-phagocytic host cells, has many binding domains for fibronectin and a specific domain for fibrinogen. It was demonstrated that the invasive capacity and internalization of L. lactis FnBPA+ into Caco-2 cells was comparable to the observed in L. lactis InlA+ [136].

Recently, the L. lactis FnBPA + strain harbouring the pValac:BLG plasmid showed increased DNA plasmid transfer both in vitro and in vivo. This strain was capable of producing up to 30 times more BLG in Caco-2 cells than the non-invasive L. lactis p Valac:BLG strain and increased the number of mice producing BLG [132]. In order to avoid the use of this lactococci strain, De Azevedo et al. constructed a new L. lactis strain that produces a previously described mutated form of InlA (mInlA) and that allows binding to murine E-cadherin. The plasmid transfer in vitro using L. lactis mInlA + BLG increased 10 times compared to the wild type strain and the number of mice producing BLG in isolated enterocytes after oral administration was slightly higher [115].

All these approaches confirm the high potential of invasive recombinant lactococci strains as DNA delivery vector in vivo. Moreover, these strategies combine the advantages of mucosal immunization with the simplicity of the technique and low cost of DNA vaccines, as well as the secure use of these bacteria. In this context, the use of non-invasive and invasive L. lactis strains for the delivery of plasmids expressing molecules of interest could be a good, efficient, economical and safe strategy for the development of DNA vaccines for the control of a diverse array of diseases.

\section{Approved DNA Vaccines}

Four DNA vaccines have already been approved for veterinary use, being two of them prophylactic vaccines against infectious diseases, one for cancer immunotherapy and one for gene therapy (Table 4). 
Table 4. DNA vaccines approved for veterinary use.

\begin{tabular}{|c|c|c|c|c|c|c|}
\hline Type & Species & Target & Product/Company & $\begin{array}{l}\text { License date/ } \\
\text { country }\end{array}$ & $\begin{array}{c}\text { Route of } \\
\text { administration }\end{array}$ & Benefits \\
\hline $\begin{array}{l}\text { Prophylactic } \\
\text { vaccine }\end{array}$ & Horses & West Nile Virus & $\begin{array}{c}\text { West Nile-Innovator }{ }^{\circledR} / \\
\text { Fort Dodge Animal } \\
\text { Health }\end{array}$ & 2005 USA & $\mathrm{IM}^{1}$ & $\begin{array}{c}\text { Production of } \\
\text { protective antibodies }\end{array}$ \\
\hline $\begin{array}{l}\text { Prophylactic } \\
\text { vaccine }\end{array}$ & Salmon & $\begin{array}{c}\text { Infectious } \\
\text { haematopoietic } \\
\text { necrosis virus (IHNV) }\end{array}$ & $\begin{array}{c}\text { Apex-IHN }{ }^{\circledR} / \text { Novartis } \\
\text { Animal Health }\end{array}$ & 2005 Canada & $\mathrm{IM}$ & $\begin{array}{l}\text { Stimulation of innate and } \\
\text { adaptive immune responses } \\
\text { improving the welfare } \\
\text { and product yield }\end{array}$ \\
\hline $\begin{array}{c}\text { Immunotherapy } \\
\text { of cancer }\end{array}$ & Dogs & Melanoma & Oncept ${ }^{\mathrm{TM}} /$ Merial & 2010 USA & ID $^{2}$ needle-free. & $\begin{array}{l}\text { Production of antibodies } \\
\text { capable of preventing the } \\
\text { progress of the disease and } \\
\text { prolonging the animal's life }\end{array}$ \\
\hline Gene therapy & Swine & $\begin{array}{l}\text { Growth hormone } \\
\text { releasing hormone } \\
(\mathrm{GHRH})\end{array}$ & $\begin{array}{c}\text { LifeTide }^{\circledR} \\
\text { SW5/VGX } \\
\text { Animal Health }\end{array}$ & 2008 Australia & $\begin{array}{l}\text { IM followed by } \\
\text { electroporation }\end{array}$ & $\begin{array}{c}\text { Decrease in perinatal } \\
\text { mortality and morbidity, } \\
\text { increase of the number } \\
\text { of pigs weaned per sow } \\
\text { and productivity }\end{array}$ \\
\hline
\end{tabular}

In 2005, the West Nile Virus (WNV) equine DNA vaccine was licensed by the US Department of Agriculture (USDA). This vaccine contains two genes that encode WNV proteins. One advantage of this DNA vaccine is that vaccinated horses can be differentiated from those that have been naturally infected by the virus, which could be considered an important factor for public health disease monitoring activities [138] [139]. Also in 2005, the Canadian Food Inspection Agency (CFIA) licensed a DNA vaccine against the Infectious Haematopoietic Necrosis Virus. Produced by Novartis, this vaccine is commercially called Apex-IHN ${ }^{\circledR}$ and prevents infectious haematopoietic necrosis in farm-raised Atlantic salmon and is composed of a plasmid containing the gene for a glycoprotein of the virus, under the control of the pCMV promoter, and is able to stimulate innate and adaptive immune responses [17].

The first therapeutic vaccine for cancer treatment that was approved by the USDA is commercially called ONCEPT $^{\mathrm{TM}}$ (Merial). This vaccine is used for dogs affected by oral melanoma and is produced by the insertion of a non-canine gene for tyrosinase in a DNA plasmid. The tyrosine gene is present in tumour and normal cells, so no immune response against this antigen is formed. Human tyrosine is partially similar to the canine tyrosine; however, it is also partially recognized as a foreign antigen by the animal's organism and is then able to break the tolerance to this protein, inducing a strong immune response [140] [141]. A conditional license of this vaccine was available for veterinary oncologists and testing in 2007 and in 2010 it received full licensing.

Finally, a gene therapy developed for pigs demonstrated that animals that had received only one dose of the DNA plasmid were capable of expressing the natural form of the growth hormone releasing hormone (GHRH), being this result the same as that obtained for pigs that were treated with two doses of the injectable growth hormone (GH) daily during eight weeks. The injectable dose of the plasmid (pGHRH) administrated through electroporation favoured the expression of GH. Approved in 2008 by the Australian Pesticides and Veterinary Medicines Authority, pGHRHwas the first licensed therapeutic plasmid administrated via electroporation. Commercially called LifeTide ${ }^{\circledR}$ SW 5 (VGX Animal Health), this vaccine is administered in a single dose to females of reproductive age, reducing perinatal morbidity and mortality and increasing productivity [19] [20].

While some animal DNA vaccines are already being used, many human DNA vaccines are still being tested in clinical trials. Successfully tested vaccines in animal models opened the door to the development of human vaccines, using procedures approved by ethic committees. Testing DNA vaccines in clinical trials is important to obtain information about adverse effects, safety and efficacy of the vaccine and vaccination procedure. Clinical trials are composed of four sequential phases. In Phase I, the experimental vaccine is administered to a group of 20 - 80 people to evaluate the safety and proper dosing of the vaccine and identify its side effects. In Phase II the efficacy and safety are evaluated in a larger group of individuals (100 - 300), while in Phase III the vaccine is tested in an even larger group of people (1000 - 3000) and compared to conventional treatments, in order to provide information on their safe use, effectiveness and side effects. Finally, in Phase IV, post marketing studies de- 
lineate additional information, including the drug's risks, benefits and optimal use (www.clinicaltrials.gov).

A HIV-1 vaccine clinical trial phase I study was performed in healthy HIV-1-uninfected adults using the PENNVAX ${ }^{\circledR}$-B DNA vaccine (PV is a mixture of 3 expression plasmids encoding HIV-1 Clade B Env, Gag, and Pol) and a DNA plasmid expressing human interleukin 12 (IL-12). Cellular immune responses were analysed after four intramuscular vaccine administration or three intramuscular administrations by electroporation. This trial showed that this vaccine was safe and well tolerated by patients and that the administration of PV and IL-12 by electroporation had a significant dose-sparing effect and provided higher immunogenicity to that observed in the trial without electroporation, showing the power of combining DNA approaches to generate stronger immune responses in humans [142].

Sadly, until now no licensed human DNA vaccines exist, but the results obtained with the commercialized veterinary vaccines and the various human clinical trials that are under study are increasing the reliability of this vaccine platform, greatly raising hopes for the successful development of human vaccines and therapies. However, a lot of effort and work is still necessary to improve the different DNA vaccine platforms to certify their safety and immunological efficiency.

\section{Conclusion}

DNA vaccine is a simple concept with a complex mechanism of action that represents a feasible strategy for world health today. The proof of this is that four DNA vaccines that have proved to be efficient for prophylaxis against infectious diseases, cancer immunotherapy and gene therapy have already been approved for veterinary use. Till today, no available human DNA vaccines exist, but the results obtained with the already licensed animal vaccines increases their reliability and hopes for the development of DNA vaccines for human use. Therefore, strategies designed to improve genetic vaccination efficiency are nowadays the focus of current studies with DNA vaccines.

\section{References}

[1] WHO (2008) The Global Burden of Disease: 2004 Update.

[2] Kariuki, S. and Hart, C.A. (2001) Global Aspects of Antimicrobial-Resistant Enteric Bacteria. Current Opinion in Infectious Diseases, 14, 579-586. http://dx.doi.org/10.1097/00001432-200110000-00012

[3] Threlfall, E.J. (2002) Antimicrobial Drug Resistance in Salmonella: Problems and Perspectives in Food- and WaterBorne Infections. FEMS Microbiology Reviews, 26, 141-148. http://dx.doi.org/10.1111/j.1574-6976.2002.tb00606.x

[4] van Ginkel, F.W., Nguyen, H.H. and McGhee, J.R. (2000) Vaccines for Mucosal Immunity to Combat Emerging Infectious Diseases. Emerging Infectious Diseases, 6, 123-132. http://dx.doi.org/10.3201/eid0602.000204

[5] Mielcarek, N., Alonso, S. and Locht, C. (2001) Nasal Vaccination Using Live Bacterial Vectors. Advanced Drug Delivery Reviews, 51, 55-69.

[6] Gurunathan, S., Wu, C.Y., Freidag, B.L. and Seder, R.A. (2000) DNA Vaccines: A Key for Inducing Long-Term Cellular Immunity. Current Opinion in Immunology, 12, 442-447. http://dx.doi.org/10.1016/S0952-7915(00)00118-7

[7] Levine, M.M. and Sztein, M.B. (2004) Vaccine Development Strategies for Improving Immunization: The Role of Modern Immunology. Nature Immunology, 5, 460-464. http://dx.doi.org/10.1038/ni0504-460

[8] Stasney, J., Cantarow, A. and Paschkis, K.E. (1950) Production of Neoplasms by Injection of Fractions of Mammalian Neoplasms. Cancer Research, 10, 775-782.

[9] Will, H., Cattaneo, R., Koch, H.G., Darai, G., Schaller, H., Schellekens, H., van Eerd, P.M. and Deinhardt, F. (1982) Cloned HBV DNA Causes Hepatitis in Chimpanzees. Nature, 299, 740-742.

[10] Dubensky, T.W., Campbell, B.A. and Villarreal, L.P. (1984) Direct Transfection of Viral and Plasmid DNA into the Liver or Spleen of Mice. Proceedings of the National Academy of Sciences of the United States of America, 81, 75297533. http://dx.doi.org/10.1073/pnas.81.23.7529

[11] Wolff, J.A., Malone, R.W., Williams, P., Chong, W., Acsadi, G., Jani, A. and Felgner, P.L. (1990) Direct Gene Transfer into Mouse Muscle in Vivo. Science, 247, 1465-1468. http://dx.doi.org/10.1126/science.1690918

[12] Tang, D.C., DeVit, M. and Johnston, S.A. (1992) Genetic Immunization Is a Simple Method for Eliciting an Immune Response. Nature, 356, 152-154. http://dx.doi.org/10.1038/356152a0

[13] Fynan, E.F., Webster, R.G., Fuller, D.H., Haynes, J.R., Santoro, J.C., Robinson, H.L. (1993) DNA Vaccines: Protective Immunizations by Parenteral, Mucosal and Gene-Gun Inoculations. Proceedings of the National Academy of 
Sciences of the United States of America, 90, 11478-11482. http://dx.doi.org/10.1073/pnas.90.24.11478

[14] Ulmer, J.B., Donnelly, J.J., Parker, S.E., Rhodes, G.H., Felgner, P.L., Dwarki, V.J., Gromkowski, S.H., Deck, R.R., DeWitt, C.M. and Friedman, A. (1993) Heterologous Protection against Influenza by Injection of DNA Encoding a Viral Protein. Science, 259, 1745-1749. http://dx.doi.org/10.1126/science.8456302

[15] Reyes-Sandoval, A. and Ertl, H.C. (2001) DNA Vaccines. Current Molecular Medicine, 1, 217-243. http://dx.doi.org/10.2174/1566524013363898

[16] Davidson, A.H., Traub-Dargatz, J.L., Rodeheaver, R.M., Ostlund, E.N., Pedersen, D.D., Moorhead, R.G., Stricklin, J.B., Dewell, R.D., Roach, S.D., Long, R.E., Albers, S.J., Callan, R.J. and Salman, M.D. (2005) Immunologic Responses to West Nile Virus in Vaccinated and Clinically Affected Horses. Journal of the American Veterinary Medical Association, 226, 240-245. http://dx.doi.org/10.2460/javma.2005.226.240

[17] Garver, K.A., LaPatra, S.E. and Kurath, G. (2005) Efficacy of an Infectious Hematopoietic Necrosis (IHN) Virus DNA Vaccine in Chinook Oncorhynchus tshawytscha and Sockeye O. nerka Salmon. Diseases of Aquatic Organisms, 64, 13-22. http://dx.doi.org/10.3354/dao064013

[18] Bergman, P.J., Camps-Palaua, M.A., McKnighta, J.A., Leibmana, N.F., Crafta, D.M., Leunga, C., Liaoa, J., Riviereb, I., Sadelainb, M., Hohenhausa, A.E., Gregorb, P., Houghtonb, A.N., Peralesb, M.A. and Wolchokb, J.D. (2006) Development of a Xenogeneic DNA Vaccine Program for Canine Malignant Melanoma at the Animal Medical Center. Vaccine, 24, 4582-4585. http://dx.doi.org/10.1016/j.vaccine.2005.08.027

[19] Khan, A.S., Bodles-Brakhop, A.M., Fiorotto, M.L. and Draghia-Akli, R. (2010) Effects of Maternal Plasmid GHRH Treatment on Offspring Growth. Vaccine, 28, 1905-1910. http://dx.doi.org/10.1016/j.vaccine.2009.10.093

[20] Khan, A.S., Draghia-Akli, R., Shypailo, R.J., Ellis, K.I., Mersmann, H. and Fiorotto, M.L. (2010) A Comparison of the Growth Responses Following Intramuscular GHRH Plasmid Administration versus Daily Growth Hormone Injections in Young Pigs. Molecular Therapy, 18, 327-333. http://dx.doi.org/10.1038/mt.2009.224

[21] Liu, M.A. (2010) DNA Vaccines: An Historical Perspective and View to the Future. Immunological Reviews, 239, 6284. http://dx.doi.org/10.1111/j.1600-065X.2010.00980.x

[22] Glenting, J. and Wessels S. (2005) Ensuring Safety of DNA Vaccines. Microbial Cell Factories, 4, 26. http://dx.doi.org/10.1186/1475-2859-4-26

[23] Williams, J.A., Carnes, A.E. and Hodgson, C.P. (2009) Plasmid DNA Vaccine Vector Design: Impact on Efficacy, Safety and Upstream Production. Biotechnology Advances, 27, 353-370. http://dx.doi.org/10.1016/j.biotechadv.2009.02.003

[24] Kowalczyk, D.W. and Ertl, H.C. (1999) Immune Responses to DNA Vaccines. Cellular and Molecular Life Sciences, 55, 751-770. http://dx.doi.org/10.1007/s000180050330

[25] Garmory, H.S., Leckenby, M.W., Griffin, K.F., Elvin, S.J., Taylor, R.R., Hartley, M.G., Hanak, J.A., Williamson, E.D. and Cranenburgh, R.M. (2005) Antibiotic-Free Plasmid Stabilization by Operator-Repressor Titration for Vaccine Delivery by Using Live Salmonella enteric Serovar Typhimurium. Infection and Immunity, 73, 11. http://dx.doi.org/10.1128/IAI.73.4.2005-2011.2005

[26] Mairhofer, J., Pfaffenzeller, I., Merz, D. and Grabherr, R. (2007) A Novel Antibiotic Free Plasmid Selection System: Advances in Safe and Efficient DNA Therapy. Biotechnology Journal, 3, 83-89. http://dx.doi.org/10.1002/biot.200700141

[27] Becker, P.D., Noerder, M. and Guzmán, C.A. (2008) Genetic Immunization: Bacteria as DNA Vaccine Delivery Vehicle. Human Vaccines, 4, 189-202. http://dx.doi.org/10.4161/hv.4.3.6314

[28] Papadakis, E.D., Nicklin, S.A., Baker, A.H. and White, S.J. (2004) Promoters and Control Elements: Designing Expression Cassettes for Gene Therapy. Current Gene Therapy, 4, 89-113.

[29] Vanniasinkam, T., Reddy, S.T. and Ertl, H.C. (2006) DNA Immunization Using a Non-Viral Promoter. Virology, 344, 412-420. http://dx.doi.org/10.1016/j.virol.2005.08.040

[30] Shan, S., Jiang, Y., Bu, Z., Ellis, T., Zeng, X., Edwards, J., Tian, G., Li, Y., Ge, J., Chen, H. and Fenwick, S. (2011) Strategies for Improving the Efficacy of a H6 Subtype Avian Influenza DNA Vaccine in Chickens. Journal of Virological Methods, 173, 220-226. http://dx.doi.org/10.1016/j.jviromet.2011.02.008

[31] Xu, Z.L., Mizuguchi, H., Ishii-Watabe, A., Uchida, E., Mayumi, T. and Hayakawa, T. (2002) Strength Evaluation of Transcriptional Regulatory Elements for Transgene Expression by Adenovirus Vector. Journal of Controlled Release, 81, 155-163. http://dx.doi.org/10.1016/S0168-3659(02)00059-7

[32] Li, S., MacLaughlin, F.C., Fewell, J.G., Gondo, M., Wang, J., Nicol, F., Dean, D.A. and Smith, L.C. (2001) Muscle-Specific Enhancement of Gene Expression by Incorporation of SV40 Enhancer in the Expression Plasmid. Gene Therapy, 8, 494-497. http://dx.doi.org/10.1038/sj.gt.3301419

[33] Shedlock, D.J. and Weiner, D.B. (2000) DNA Vaccination: Antigen Presentation and the Induction of Immunity. 
Journal of Leukocyte Biology, 68, 793-806.

[34] Capone, S., Zampaglione, I., Vitelli, A., Pezzanera, M., Kierstead, L., Burns, J., Ruggeri, L., Arcuri, M., Cappelletti, M., Meola, A., Ercole, B.B., Tafi, R., Santini, C., Luzzago, A., Fu, T.M., Colloca, S., Ciliberto, G., Cortese, R., Nicosia, A., Fattori, E. and Folgori, A. (2006) Modulation of the Immune Response Induced by Gene Electrotransfer of a Hepatitis C Virus DNA Vaccine in Nonhuman Primates. The Journal of Immunology, 177, 7462-7471.

[35] Fioretti, D., Iurescia, S., Fazio, V.M. and Rinaldi, M. (2010) DNA Vaccines: Developing New Strategies against Cancer. Journal of Biomedicine and Biotechnology, 2010, Article ID: 174378. http://dx.doi.org/10.1155/2010/174378

[36] Manam, S., Ledwith, B.J., Barnum, A.B., Troilo, P.J., Pauley, C.J., Harper, L.B., Griffiths, T.G., Niu, Z., Denisova, L., Follmer, T.T., Pacchione, S.J., Wang, Z., Beare, C.M., Bagdon, W.J. and Nichols, W.W. (2000) Plasmid DNA Vaccines: Tissue Distribution and Effects of DNA Sequence, Adjuvants and Delivery Method on Integration into Host DNA. Intervirology, 43, 273-281. http://dx.doi.org/10.1159/000053994

[37] Ledwith, B.J., Manam, S., Troilo, P.J., Barnum, A.B., Pauley, C.J., Griffiths, T.G., Harper, L.B., Beare, C.M., Bagdon, W.J. and Nichols, W.W. (2000) Plasmid DNA Vaccines: Investigation of Integration into Host Cellular DNA Following Intramuscular Injection in Mice. Intervirology, 43, 258-272. http://dx.doi.org/10.1159/000053993

[38] Pal, R., Yu, Q., Wang, S., Kalyanaraman, V.S., Nair, B.C., Hudacik, L., Whitney, S., Keen, T., Hung, C.L., Hocker, L., Kennedy, J.S., Markham, P. and Lu, S. (2006) Definitive Toxicology and Biodistribution Study of a Polyvalent DNA Prime/Protein Boost Human Immunodeficiency Virus Type 1 (HIV-1) Vaccine in Rabbits. Vaccine, 24, 1225-1234. http://dx.doi.org/10.1016/j.vaccine.2005.07.112

[39] Sheets, R.L. , Stein, J., Manetz, T.S., Duffy, C., Nason, M., Andrews, C., Kong, W.P., Nabel, G.J. and Gomez, P.L. (2006) Biodistribution of DNA Plasmid Vaccines against HIV-1, Ebola, Severe Acute Respiratory Syndrome, or West Nile Virus Is Similar, without Integration, Despite Differing Plasmid Backbones or Gene Inserts. Toxicological Sciences, 91, 610-619. http://dx.doi.org/10.1093/toxsci/kfj169

[40] Bagarazzi, M.L., Boyer, J.D., Javadian, M.A., Chattergoon, M., Dang, K., Kim, G., Shah, J., Wang, B. and Weiner, D.B. (1997) Safety and Immunogenicity of Intramuscular and Intravaginal Delivery of HIV-1 DNA Constructs to Infant Chimpanzees. Journal of Medical Primatology, 26, 27-33. http://dx.doi.org/10.1111/j.1600-0684.1997.tb00316.x

[41] MacGregor, R.R., Boyer, J.D., Ugen, K.E., Lacy, K.E.,Gluckman, S.J., Bagarazzi, M.L., Chattergoon, M.A., Baine, Y., Higgins, T.J., Ciccarelli, R.B., Coney, L.R., Ginsberg, R.S. and Weiner, D.B. (1998) First Human Trial of a DNABased Vaccine for Treatment of Human Immunodeficiency Virus Type 1 Infection: Safety and Host Response. The Journal of Infectious Diseases, 178, 92-100. http://dx.doi.org/10.1086/515613

[42] Le, T.P., Coonan, K.M., Hedstrom, R.C., Charoenvit, Y., Sedegah, M., Epstein, J.E., Kumar, S., Wang, R., Doolan, D. L., Maguire, J.D., Parker, S.E., Hobart, P., Norman, J. and Hoffman, S.L. (2000) Safety, Tolerability and Humoral Immune Responses after Intramuscular Administration of a Malaria DNA Vaccine to Healthy Adult Volunteers. Vaccine, 18, 1893-1901. http://dx.doi.org/10.1016/S0264-410X(99)00407-7

[43] Vaughan, E.E. and Dean, D.A. (2006) Intracellular Trafficking of Plasmids during Transfection Is Mediated by Microtubules. Molecular Therapy, 13, 422-428. http://dx.doi.org/10.1016/j.ymthe.2005.10.004

[44] Payette, P.J., Weeratna, R.D., McCluskie, M.J. and Davis, H.L. (2001) Immune-Mediated Destruction of Transfected Myocytes Following DNA Vaccination Occurs via Multiple Mechanisms. Gene Therapy, 8, 1395-1400. http://dx.doi.org/10.1038/sj.gt.3301534

[45] You, Z., Huang, X., Hester, J., Toh, H.C. and Chen, S.Y. (2001) Targeting Dendritic Cells to Enhance DNA Vaccine Potency. Cancer Research, 61, 3704-3711.

[46] Doria-Rose, N.A. and Haigwood, N.L. (2003) DNA Vaccine Strategies: Candidates for Immune Modulation and Immunization Regimens. Methods, 31, 207-216. http://dx.doi.org/10.1016/S1046-2023(03)00135-X

[47] Cherif, M.S., Shuaibu, M.N., Kurosaki, T., Helegbe, G.K., Kikuchi, M., Yanagi, T., Tsuboi, T., Sasaki, H. and Hirayama, K. (2011) Immunogenicity of Novel Nanoparticle-Coated MSP-1 C-Terminus Malaria DNA Vaccine Using Different Routes of Administration. Vaccine, 29, 9038-9050. http://dx.doi.org/10.1016/j.vaccine.2011.09.031

[48] Holmgren, J. and Czerkinsky, C. (2005) Mucosal Immunity and Vaccines. Nature Medicine, 11, S45-S53. http://dx.doi.org/10.1038/nm1213

[49] Kanazawa, T., Takashima, Y., Hirayama, S. and Okada, H. (2008) Effects of Menstrual Cycle on Gene Transfection through Mouse Vagina for DNA Vaccine. International Journal of Pharmaceutics, 360, 164-170. http://dx.doi.org/10.1016/j.ijpharm.2008.04.038

[50] Brave, A., Hallengard, D., Schroder, U., Blomberg, P., Wahren, B. and Hinkula, J. (2008) Intranasal Immunization of Young Mice with a Multigene HIV-1 Vaccine in Combination with the N3 Adjuvant Induces Mucosal and Systemic Immune Responses. Vaccine, 26, 5075-5078. http://dx.doi.org/10.1016/j.vaccine.2008.03.066

[51] Chatel, J.M., Pothelune, L., Ah-Leung, S., Corthier, G., Wal, J.M. and Langella, P. (2008) In Vivo Transfer of Plasmid from Food-Grade Transiting Lactococci to Murine Epithelial Cells. Gene Therapy, 15, 1184-1190. 
[52] Heystek, H.C., Moulon, C., Woltman, A.M., Garonne, P. and van Kooten, C. (2002) Human Immature Dendritic Cells Efficiently Bind and Take Up Secretory IgA without the Induction of Maturation. The Journal of Immunology, 168, 102-107.

[53] Lavelle, E.C. and O’Hagan, D.T. (2006) Delivery Systems and Adjuvants for Oral Vaccines. Expert Opinion on Drug Delivery, 3, 747-762. http://dx.doi.org/10.1517/17425247.3.6.747

[54] Neutra, M.R. and Kozlowski, P.A. (2006) Mucosal Vaccines: The Promise and the Challenge. Nature Reviews Immunology, 6, 148-158. http://dx.doi.org/10.1038/nri1777

[55] Wells, J. (2011) Mucosal Vaccination and Therapy with Genetically Modified Lactic Acid Bacteria. Annual Review of Food Science and Technology, 2, 423-445. http://dx.doi.org/10.1146/annurev-food-022510-133640

[56] Brandtzaeg, P., Kiyono, H., Pabst, R. and Russell, M.W. (2008) Terminology: Nomenclature of Mucosa-Associated Lymphoid Tissue. Mucosal Immunology, 1, 31-37. http://dx.doi.org/10.1038/mi.2007.9

[57] Kaiserlian, D. and Etchart, N. (1999) Entry Sites for Oral Vaccines and Drugs: A Role for M Cells, Enterocytes and Dendritic Cells? Seminars in Immunology, 11, 217-224. http://dx.doi.org/10.1006/smim.1999.0177

[58] Shalaby, W.S. (1995) Development of Oral Vaccines to Stimulate Mucosal and Systemic Immunity: Barriers and Novel Strategies. Clinical Immunology and Immunopathology, 74, 127-134. http://dx.doi.org/10.1006/clin.1995.1019

[59] Brandtzaeg, P., Farstad, I.N., Haraldsen, G. and Jahnsen, F.L. (1998) Cellular and Molecular Mechanisms for Induction of Mucosal Immunity. Developments in Biological Standardization, 92, 93-108.

[60] Chadwick, S., Kriegel, C. and Amiji, M. (2009) Delivery Strategies to Enhance Mucosal Vaccination. Expert Opinion on Biological Therapy, 9, 427-440. http://dx.doi.org/10.1517/14712590902849224

[61] Calarota, S.A. and Weiner, D.B. (2004) Enhancement of Human Immunodeficiency Virus Type 1-DNA Vaccine Potency through Incorporation of T-Helper 1 Molecular Adjuvants. Immunological Reviews, 199, 84-99. http://dx.doi.org/10.1111/j.0105-2896.2004.00150.x

[62] Kim, M.S. and Sin, J.I. (2005) Both Antigen Optimization and Lysosomal Targeting Are Required for Enhanced Anti-Tumour Protective Immunity in a Human Papillomavirus E7-Expressing Animal Tumour Model. Immunology, 116, 255-266. http://dx.doi.org/10.1111/j.1365-2567.2005.02219.x

[63] Li, K.B., Zhang, X.G., Ma, J., Jia, X.J., Wang, M., Dong, J., Zhang, X.M., Xu, H. and Shu, Y.L. (2008) Codon Optimization of the H5N1 Influenza Virus HA Gene Gets High Expression in Mammalian Cells. Chinese Journal of Virology, 24, 101-105.

[64] Uchijima, M., Yoshida, A., Nagata, T. and Koide, Y. (1998) Class I-Restricted T Cell Responses against Vaccine Is Required for the Effective MHC Optimization of Codon Usage of Plasmid DNA an Intracellular Bacterium. The Journal of Immunology, 161, 5594-5599.

[65] Pulsawat, P., Piboonpocanun, S., Sirivichayakul, S., Buranapraditkun, S., Jacquet, A., Shimada, M., Okuda, K. and Ruxrungtham, K.J. (2010) Production and Immunogenicity of Hypoallergenic Codon-Optimized DNA Vaccine encoding Mature Der p 1 Allergen. Journal of Investigational Allergology and Clinical Immunology, 20, 582-590.

[66] Besse, F. and Ephrussi, A. (2008) Translational Control of Localized mRNAs: Restricting Protein Synthesis in Space and Time. Nature Reviews Molecular Cell Biology, 9, 971-980. http://dx.doi.org/10.1038/nrm2548

[67] Kumagai, Y., Takeuchi, O. and Akira, S. (2008) TLR9 as a Key Receptor for the Recognition of DNA. Advanced Drug Delivery Reviews, 60, 795-804. http://dx.doi.org/10.1016/j.addr.2007.12.004

[68] Angel, J.B., Cooper, C.L., Clinch, J., Young, C.D., Chenier, A., Parato, K.G., Lautru, M., Davis, H. and Cameron, D.W. (2008) CpG Increases Vaccine Antigen-Specific Cell-Mediated Immunity When Administered with Hepatitis B vaccine In HIV Infection. Journal of Immune Based Therapies and Vaccines, 6, 4. http://dx.doi.org/10.1186/1476-8518-6-4

[69] Xu, Z.L., Mizuguchi, H., Ishii-Watabe, A., Uchida, E., Mayumi, T. and Hayakawa, T. (2001) Optimization of Transcriptional Regulatory Elements for Constructing Plasmid Vectors. Gene, 272, 149-156. http://dx.doi.org/10.1016/S0378-1119(01)00550-9

[70] Chong, S.Y., Egan, M.A., Kutzler, M.A., Megati, S., Masood, A., Roopchard, V., Garcia-Hand, D., Montefiori, D.C., Quiroz, J., Rosati, M., Schadeck, E.B., Boyer, J.D., Pavlakis, G.N., Weiner, D.B., Sidhu, M., Eldridge, J.H. and Israel, Z.R. (2007) Comparative Ability of Plasmid IL-12 and IL-15 to Enhance Cellular and Humoral Immune Responses Elicited by a SIVgag Plasmid DNA Vaccine and Alter Disease Progression Following SHIV(89.6P) Challenge in Rhesus Macaques. Vaccine, 25, 4967-4982. http://dx.doi.org/10.1016/j.vaccine.2006.11.070

[71] Wang, Q.M., Sun, S.H., Hu, Z.L., Yin, M., Xiao, C.J. and Zhang, J.C. (2004) Improved Immunogenicity of a Tuberculosis DNA Vaccine Encoding ESAT6 by DNA Priming and Protein Boosting. Vaccine, 22, 3622-3627. http://dx.doi.org/10.1016/j.vaccine.2004.03.029

[72] Reyes-Sandoval, A. and Ertl, H.C. (2001) DNA Vaccines. Current Molecular Medicine, 1, 217-243. 
http://dx.doi.org/10.2174/1566524013363898

[73] Dale, C.J., Thomson, S., De Rose, R., Ranasinghe, C., Medveczky, C.J., Pamungkas, J., Boyle, D.B., Ramshaw, I.A. and Kent, S.J. (2006) Prime-Boost Strategies in DNA Vaccines. Methods in Molecular Medicine, 127, 171-197.

[74] Kent, S., De Rose, R. and Rollman, E. (2007) Drug Evaluation: DNA/MVA Prime-Boost HIV Vaccine. Current Opinion in Investigational Drugs, 8, 159-167.

[75] Patterson, L.J. and Robert-Guroff, M. (2008) Replicating Adenovirus Vector Prime/Protein Boost Strategies for HIV Vaccine Development. Expert Opinion on Biological Therapy, 8, 1347-1363. http://dx.doi.org/10.1517/14712598.8.9.1347

[76] Pan, Z., Zhang, X., Geng, S., Cheng, N., Sun, L., Liu, B., Huang, J. and Jiao, X. (2009) Priming with a DNA Vaccine Delivered by Attenuated Salmonella typhimurium and Boosting with a Killed Vaccine Confers Protection of Chickens against Infection with the H9 Subtype of Avian Influenza Virus. Vaccine, 27, 1018-1023. http://dx.doi.org/10.1016/j.vaccine.2008.11.111

[77] Fan, X., Gao, Q. and Fu, R. (2007) DNA Vaccine Encoding ESAT-6 Enhances the Protective Efficacy of BCG against Mycobacterium tuberculosis Infection in Mice. Scandinavian Journal of Immunology, 66, 523-528. http://dx.doi.org/10.1111/j.1365-3083.2007.02006.x

[78] Lu, J., Wang, C., Zhou, Z., Ying Zhang, Cao, T., Shi, C., Chen, Z., Chen, L., Cai, C. and Fan, X. (2011) Immunogenicity and Protective Efficacy against Murine Tuberculosis of a Prime-Boost Regimen with BCG and a DNA Vaccine Expressing ESAT-6 and Ag85A Fusion Protein. Clinical and Developmental Immunology, 2011, Article ID: 617892. http://dx.doi.org/10.1155/2011/617892

[79] Moore, A.C. and Hill, A.V. (2004) Progress in DNA-Based Heterologous Prime-Boost Immunization Strategies for Malaria. Immunological Reviews, 199, 126-143. http://dx.doi.org/10.1111/j.0105-2896.2004.00138.x

[80] Dean, D.A. (1997) Import of Plasmid DNA into the Nucleus Is Sequence Specific. Experimental Cell Research, 230, 293-302. http://dx.doi.org/10.1006/excr.1996.3427

[81] Dean, D.A., Dean, B.S., Muller, S. and Smith, L.C. (1999) Sequence Requirements for Plasmid Nuclear Import. Experimental Cell Research, 253, 713-722. http://dx.doi.org/10.1006/excr.1999.4716

[82] Vacik, J., Dean, B.S., Zimmer, W.E. and Dean, D.A. (1999) Cell-Specific Nuclear Import of Plasmid DNA. Gene Therapy, 6, 1006-1014. http://dx.doi.org/10.1038/sj.gt.3300924

[83] Young, J.L., Benoir, J.N. and Dean, D.A. (2003) Effect of a DNA Nuclear Targeting Sequence on Gene Transfer and Expression of Plasmids in the Intact Vasculature. Gene Therapy, 10, 1465-1470. http://dx.doi.org/10.1038/sj.gt.3302021

[84] Young, J.L., Zimmer, W.E. and Dean, D.A. (2008) Smooth Muscle-Specific Gene Delivery in the Vasculature Based on Restriction of DNA Nuclear Import. Experimental Biology and Medicine, 233, 840-848. http://dx.doi.org/10.3181/0712-RM-331

[85] Mesika, A., Grigoreva, I., Zohar, M. and Reich, Z. (2001) A Regulated, NFkappaB-Assisted Import of Plasmid DNA into Mammalian cell Nuclei. Molecular Therapy, 3, 653-657. http://dx.doi.org/10.1006/mthe.2001.0312

[86] Langle-Rouault, F., Patzel, V., Benavente, A., Taillez, M., Silvestre, N., Bompard, A., Sczakiel, G., Jacobs, E. and Rittner, K. (1998) Up to 100-Fold Increase of Apparent Gene Expression in the Presence of Epstein-Barr Virus oriP Sequences and EBNA1: Implications of the Nuclear Import of Plasmids. Journal of Virology, 72, 6181-6185.

[87] Vaysse, L., Harbottle, R., Bigger, B., Bergau, A., Tolmachov, O. and Coutelle, C. (2004) Development of a Self-Assembling Nuclear Targeting Vector System Based on the Tetracycline Repressor Protein. The Journal of Biological Chemistry, 279, 5555-5564. http://dx.doi.org/10.1074/jbc.M311894200

[88] Pichon, C., Billiet, L. and Midoux, P. (2010) Chemical Vectors for Gene Delivery: Uptake and Intracellular Trafficking. Current Opinion in Biotechnology, 21, 640-645. http://dx.doi.org/10.1016/j.copbio.2010.07.003

[89] Thomas, C.E., Ehrhardt, A. and Kay, M.A. (2003) Progress and Problems with the Use of Viral Vectors for Gene Therapy. Nature Reviews Genetics, 4, 346-358. http://dx.doi.org/10.1038/nrg1066

[90] Naldini, L., Blömer, U., Gage, F.H., Trono, D. and Verma, I.M. (1996) Efficient Transfer, Integration, and Sustained Long-Term Expression of the Transgene in Adult Rat Brains Injected with a Lentiviral Vector. Proceedings of the National Academy of Sciences of the United States of America, 93, 11382-11388. http://dx.doi.org/10.1073/pnas.93.21.11382

[91] Verma, I.M. and Weitzman, M.D. (2005) Gene Therapy: Twenty-First Century Medicine. Annual Review of Biochemistry, 74, 711-738. http://dx.doi.org/10.1146/annurev.biochem.74.050304.091637

[92] Casimiro, D.R., Chen, L., Fu, T.M., Evans, R.K., Caulfield, M.J., Davies, M.E., Tang, A., Chen, M., Huang, L., Harris, V., Freed, D.C., Wilson, K.A., Dubey, S., Zhu, D.M., Nawrocki, D., Mach, H., Troutman, R., Isopi, L., Williams, D., Hurni, W., Xu, Z., Smith, J.G., Wang, S., Liu, X., Guan, L., Long, R., Trigona, W., Heidecker, G.J., Perry, H.C., Per- 
saud, N., Toner, T.J., Su, Q., Liang, X., Youil, R., Chastain, M., Bett, A.J., Volkin, D.B., Emini, E.A. and Shiver, J.W. (2003) Comparative Immunogenicity in Rhesus Monkeys of DNA Plasmid, Recombinant Vaccinia Virus, and Replication-Defective Adenovirus Vectors Expressing a Human Immunodeficiency Virus Type 1 Gag Gene. Journal of Virology, 77, 6305-6313. http://dx.doi.org/10.1128/JVI.77.11.6305-6313.2003

[93] Catanzaro, A.T., Koup, R.A., Roederer, M., Bailer, R.T., Enama, M.E., Moodie, Z., Gu, L., Martin, J.E., Novik, L., Chakrabarti, B.K., Butman, B.T., Gall, J.G., King, C.R., Andrews, C.A., Sheets, R., Gomez, P.L., Mascola, J.R., Nabel, G.J. and Graham, B.S. (2006) Phase 1 Safety and Immunogenicity Evaluation of a Multiclade HIV-1 Candidate Vaccine Delivered by a Replication-Defective Recombinant Adenovirus Vector. The Journal of Infectious Diseases, 194, 1638-1649. http://dx.doi.org/10.1086/509258

[94] Lee, H.J., Park, N., Cho, H.J., Yoon, J.K., Van, N.D., Oh, Y.K. and Kim, Y.B. (2009) Development of a Novel Viral DNA Vaccine against Human Papillomavirus: AcHERV-HP16L1. Vaccine, 28, 1613-1619. http://dx.doi.org/10.1016/j.vaccine.2009.11.044

[95] Van DrunenLittel-van den Hurk, S., Gerdts, V., Loehr, B.I., Pontarollo, R., Rankin, R., Uwiera, R. and Babiuk, L.A. (2000) Recent Advances in the Use of DNA Vaccines for the Treatment of Diseases of Farmed Animals. Advanced Drug Delivery Reviews, 43, 13-28. http://dx.doi.org/10.1016/S0264-410X(02)00574-1

[96] Babuik, L.A., Pontarollo, R., Babiuk, S., Loehr, B. and Van Drunen Little-van den Hurk, S. (2003) Induction of Immune Responses by DNA Vaccines in Large Animals. Vaccine, 21, 649-658.

[97] Palumbo, R.N., Zhong, X., Panus, D., Han, W., Ji, W. and Wang, C. (2012) Transgene Expression and Local Tissue Distribution of Naked and Polymer-Condensed Plasmid DNA after Intradermal Administration in Mice. Journal of Controlled Release, 159, 232-239. http://dx.doi.org/10.1016/j.jconrel.2012.01.012

[98] Lodmell, D.L., Ray, N.B. and Ewalt, L.C. (1998) Gene Gun Particle Mediated Vaccination with Plasmid DNA Confers Protective Immunity against Rabies Virus Infection. Vaccine, 16, 115-118. http://dx.doi.org/10.1016/S0264-410X(97)88325-9

[99] Yoshida, A., Nagata, T., Uchijima, M., Higashi, T. and Koide, Y. (2000) Advantage of Gene Gun-Mediated over Intramuscular Inoculation of Plasmid DNA Vaccine in Reproducible Induction of Specific Immune Responses. Vaccine, 18, 1725-1729. http://dx.doi.org/10.1016/S0264-410X(99)00432-6

[100] Fuller, D.H., Loudon, P. and Schmaljohn, C. (2006) Preclinical and Clinical Progress of Particle-Mediated DNA Vaccines for Infectious Diseases. Methods, 40, 86-97. http://dx.doi.org/10.1016/j.ymeth.2006.05.022

[101] Tacket, C.O., Roy, M.J., Widera, G., Swain, W.F., Broome, S. and Edelman, R. (1999) Phase 1 Safety and Immune Response Studies of a DNA Vaccine Encoding Hepatitis B Surface Antigen Delivered by a Gene Delivery Device. Vaccine, 17, 2826-2829. http://dx.doi.org/10.1016/S0264-410X(99)00094-8

[102] Dileo, J., Miller, J.R., Chesnoy, S. and Huang, L. (2003) Gene Transfer to Subdermal Tissues via a New Gene Gun Design. Human Gene Therapy, 14, 79-87. http://dx.doi.org/10.1089/10430340360464732

[103] Trimble. C., Lin, C.T., Hung, C.F., Pai, S., Juang, J., He, L., Gillison, M., Pardoll, D., Wu, L. and Wu, T.C. (2003) Comparison of the CD8+ T Cell Responses and Antitumor Effects Generated by DNA Vaccine Administered through Gene Gun, Biojector, and Syringe. Vaccine, 21, 4036-4042.

[104] Parham, J., Iannone, M., Overton, L. and Hutchins, J. (1998) Optimization of Transient Gene Expression in Mammalian Cells and Potential for Scale-Up Using Flow Lectroporation. Cytotechnology, 28, 147-155. http://dx.doi.org/10.1023/A:1008046101653

[105] Kima, J., Choa, K., Shin, Y., Jung, N., Chunga, C. and Changa, J. (2007) A Multi-Channel Electroporation Microchip for Gene Transfection in Mammalian Cells. Biosensors and Bioelectronics, 22, 3273-3277. http://dx.doi.org/10.1016/j.bios.2007.02.009

[106] Canatella, P.J., Karr, J.F., Petros, J.A. and Prausnitz, M.R. (2001) Quantitative Study of Electroporation Mediated Molecular Uptake and Cell Viability. Biophysical Journal, 80, 755-764. http://dx.doi.org/10.1016/S0006-3495(01)76055-9

[107] Gursel, I., Gursel, M., Ishii, K.J. and Klinman, D.M. (2001) Sterically Stabilized Cationic Liposomes Improve the Uptake and Immunostimulatory Activity of CpG Oligonucleotides. The Journal of Immunology, 167, 3324e8.

[108] Godbey, W.T., Wu, K.K. and Mikos, A.G. (1999) Tracking the Intracellular Path of Poly(Ethylenimine)/DNA Complexes for Gene Delivery. Proceedings of the National Academy of Sciences of the United States of America, 96, 51775181. http://dx.doi.org/10.1073/pnas.96.9.5177

[109] Vuorimaa, E., Urtti, A., Seppanen, R., Lemmetyinen, H. and Yliperttula, M. (2008) Time-Resolved Fluorescence Spectroscopy Reveals Functional Differences of Cationic Polymer DNA Complexes. Journal of the American Chemical Society, 130, 11695-11700. http://dx.doi.org/10.1021/ja801503h

[110] Kircheis, R., Wightman, L. and Wagner, E. (2001) Design and Gene Delivery Activity of Modified Polyethylenimines. Advanced Drug Delivery Reviews, 53, 341-358. http://dx.doi.org/10.1016/S0169-409X(01)00202-2 
[111] Ai, H., Jones, S.A., de Villiers, M.M. and Lvov, Y.M. (2003) Nano-Encapsulation of Furosemide Microcrystals for Controlled Drug Release. Journal of Controlled Release, 86, 59-68. http://dx.doi.org/10.1016/S0168-3659(02)00322-X

[112] Garzon, M.R., Berraondo, P., Crettaz, J., Ochoa, L., Vera, M., Lasarte, J.J., Vales, A., Van Rooijen, N., Ruiz, J., Prieto, J., Zulueta, J. and González-Aseguinolaza, G. (2005) Induction of gp120-Specific Protective Immune Responses by Genetic Vaccination with Linear Polyethylenimine-Plasmid Complex. Vaccine, 23, 1384-1392. http://dx.doi.org/10.1016/j.vaccine.2004.09.009

[113] Kasturi, S.P., Sachaphibulkij, K. and Roy, K. (2005) Covalent Conjugation of Polyethyleneimine on Biodegradable Microparticles for Delivery of Plasmid DNA Vaccines. Biomaterials, 26, 6375-6385. http://dx.doi.org/10.1016/j.biomaterials.2005.03.043

[114] Orson, F.M., Kinsey, B.M., Densmore, C.L., Nguyen, T., Wu, Y., Mbawuike, I.N. and Wyde, P.R. (2006) Protection against Influenza Infection by Cytokine-Enhanced Aerosol Genetic Immunization. The Journal of Gene Medicine, 8, 488-497. http://dx.doi.org/10.1002/jgm.864

[115] de Azevedo, M., Karczewski, J., Lefévre, F., Azevedo, V., Miyoshi, A., Wells, J.M., Langella, P. and Chatel, J.M. (2012) In Vitro and in Vivo Characterization of DNA Delivery Using Recombinant Lactococcus lactis Expressing a Mutated Form of L. monocytogenes Internalin A. BMC Microbiology, 12, 299. http://dx.doi.org/10.1186/1471-2180-12-299

[116] Schaffner, W. (1980) Direct Transfer of Cloned Genes from Bacteria to Mammalian Cells. Proceedings of the National Academy of Sciences of the United States of America, 77, 2163-2167. http://dx.doi.org/10.1073/pnas.77.4.2163

[117] Grillot-Courvalin, C., Goussard, S. and Courvalin, P. (1999) Bacteria as Gene Delivery Vectors for Mammalian Cells. Current Opinion in Biotechnology, 10, 477-481. http://dx.doi.org/10.1016/S0958-1669(99)00013-0

[118] Schoen, C., Stritzker, J., Goebel, W. and Pilgrim, S. (2004) Bacteria as DNA Vaccine Carriers for Genetic Immunization. International Journal of Medical Microbiology, 294, 319-335. http://dx.doi.org/10.1016/j.ijmm.2004.03.001

[119] Hoebe, K., Janssen, E. and Beutler, B. (2004) The Interface between Innate and Adaptive Immunity. Nature Immunology, 5, 971-974. http://dx.doi.org/10.1038/ni1004-971

[120] Pilgrim, S., Stritzker, J., Schoen, C., Kolb-Mäurer, A., Geginat, G., Loessner, M.J., Gentschev, I. and Goebel, W. (2003) Bactofection of Mammalian Cells by Listeria monocytogenes: Improvement and Mechanism of DNA Delivery. Gene Therapy, 10, 2036-2045. http://dx.doi.org/10.1038/sj.gt.3302105

[121] Fennelly, G.J., Khan, S.A., Abadi, M.A., Wild, T.F. and Bloom, B.R. (1999) Mucosal DNA Vaccine Immunization against Measles with a Highly Attenuated Shigella Flexneri Vector. The Journal of Immunology, 162, 1603-1610.

[122] Shata, M.T. and Hone, D.M. (2001) Vaccination with a Shigella DNA Vaccine Vector Induces Antigen-Specific CD8 ${ }^{+}$ T Cells and Antiviral Protective Immunity. Journal of Virology, 75, 9665-9670. http://dx.doi.org/10.1128/JVI.75.20.9665-9670.2001

[123] Woo, P.C.Y., Wong, L., Zheng, B. and Yuen, K. (2001) Unique Immunogenicity of Hepatitis B Virus DNA Vaccine Presented by Live-Attenuated Salmonella typhimurium. Vaccine, 19, 2945-2954. http://dx.doi.org/10.1016/S0264-410X(00)00530-2

[124] Zheng, B., Woo, P.C.Y., Ng, M., Tsoi, H., Wong, L. and Yuen, K. (2001) A Crucial Role of Macrophages in the Immune Responses to oral DNA Vaccination against Hepatitis B Virus in a Murine Model. Vaccine, 20, 140-147. http://dx.doi.org/10.1016/S0264-410X(01)00272-9

[125] Miki, K., Nagata, T., Tanaka, T., Kim, Y.H., Uchijima, M., Ohara, N., Nakamura, S., Okada, M. and Koide, Y. (2004) Induction of Protective Cellular Immunity against Mycobacterium tuberculosis by Recombinant Attenuated Self-Destructing Listeria monocytogenes Strains Harboring Eukaryotic Expression Plasmids for Antigen 85 Complex and MPB/MPT51. Infection and Immunity, 72, 2014-2021. http://dx.doi.org/10.1128/IAI.72.4.2014-2021.2004

[126] Dunham, S.P. (2002) The Application of Nucleic Acid Vaccines in Veterinary Medicine. Research in Veterinary Science, 73, 9-16. http://dx.doi.org/10.1016/S0034-5288(02)00032-2

[127] Pontes, D.S., de Azevedo, M.S.P., Chatel, J.M., Langella, P., Azevedo, V. and Miyoshi, A. (2011) Lactococcus lactis as a Live Vector: Heterologous Protein Production and DNA Delivery Systems. Protein Expression and Purification, 79, 165-175. http://dx.doi.org/10.1016/j.pep.2011.06.005

[128] Wells, J.M. and Mercenier, A. (2008) Mucosal Delivery of Therapeutic and Prophylactic Molecules Using Lactic Acid Bacteria. Nature, 1038, 1-14.

[129] Guimarães, V.D., Innocentin, S., Lefèvre, F., Azevedo, V., Wal, J.M., Langella, P. and Chatel, J.M. (2006) Use of Native Lactococci as Vehicles for Delivery of DNA into Mammalian Epithelial Cells. Applied and Environmental Microbiology, 72, 7091-7097. http://dx.doi.org/10.1128/AEM.01325-06

[130] Gram, G. J., Fomsgaard, A., Thorn, M., Madsen, S.M. and Glenting, J. (2007) Immunological Analysis of a Lactococcus lactis-Based DNA Vaccine Expressing HIV gp120. Genetic Vaccines and Therapy, 5, 3.

[131] Tao, L., Pavlova, S.I., Ji, X., Jin, L. and Spear, G. (2011) A Novel Plasmid for Delivering Genes into Mammalian Cells 
with Noninvasive Food and Commensal Lactic Acid Bacteria. Plasmid, 65, 8-14. http://dx.doi.org/10.1016/j.plasmid.2010.09.001

[132] Pontes, D., Innocentin, S., Del Carmen, S., Almeida, J.F., Leblanc, J.G., de Moreno de Leblanc, A., Blugeon, S., Cherbuy, C., Lefèvre, F., Azevedo, V., Miyoshi, A., Langella, P. and Chatel, J.M. (2012) Production of Fibronectin Binding Protein A at the Surface of Lactococcus lactis Increases Plasmid Transfer in Vitro and in Vivo. PLoS ONE, 7, e44892. http://dx.doi.org/10.1371/journal.pone.0044892

[133] Gaillard, J.L., Berchem P., Frehel, C., Gouln, E. and Cossart, P. (1991) Entry of Listeria monocytogenes into Cells Is Mediated by Internalin, a Repeat Protein Reminiscent of Surface Antigens from GRAM-Positive Cocci. Cell, 65, 1127-1141. http://dx.doi.org/10.1016/0092-8674(91)90009-N

[134] Mengaud, J., Ohayon, H., Gounon, P., Mège, R.M. and Cossart, P. (1996) E-Cadherin Is the Receptor for Internalin, a Surface Protein Required for Entry of L. monocytogenes into Epithelial Cells. Cell, 84, 923-932. http://dx.doi.org/10.1016/S0092-8674(00)81070-3

[135] Guimarães, V.D., Gabriel, J.E., Lefèvre, F., Cabanes, D., Gruss, A., Cossart, P., Azevedo, V. and Langella, P. (2005) Internalin-Expressing Lactococcus lactis Is Able to Invade Small Intestine of Guinea Pigs and Deliver DNA into Mammalian Epithelial Cells. Microbes and Infection, 7, 836-844. http://dx.doi.org/10.1016/j.micinf.2005.02.012

[136] Innocentin, S., Guimarães, V., Miyoshi, A., Azevedo, V., Langella, P., Chatel., J.M. and Lefèvre, F. (2009) Lactococcus lactis Expressing Either Staphylococcus aureus Fibronectin-Binding Protein A or Listeria monocytogenes Internalin A Can Efficiently Internalize and Deliver DNA in Human Epithelial Cells. Applied and Environmental Microbiology, 75, 4870-4878. http://dx.doi.org/10.1128/AEM.00825-09

[137] Que, Y.A., Francois, P., Haefliger, J.A., Entenza, J.M., Vaudaux, P. and Moreillon, P. (2001) Reassessing the Role of Staphylococcus aureus Clumping Factor and Fibronectin-Binding Protein by Expression in Lactococcus lactis. Infection and Immunity, 69, 6296-6302. http://dx.doi.org/10.1128/IAI.69.10.6296-6302.2001

[138] Davis, B.S., Chang, G.J., Cropp, B., Roehrig, J.T., Martin, D.A., Mitchell, C.J., Bowen, R. and Bunning, M.L. (2001) West Nile Virus Recombinant DNA Vaccine Protects Mouse and Horse from Virus Challenge and Expresses in Vitro a Noninfectious Recombinant Antigen That Can Be Used in Enzyme-Linked Immunosorbent Assays. Journal of Virology, 75, 4040-4047. http://dx.doi.org/10.1128/JVI.75.9.4040-4047.2001

[139] Davidson, A.H., Traub-Dargatz, J.L., Rodeheaver, R.M., Ostlund, E.N., Pedersen, D.D., Moorhead, R.G., Stricklin, J.B., Dewell, R.D., Roach, S.D., Long, R.E., Albers, S.J., Callan, R.J. and Salman, M.D. (2005) Immunologic Responses to West Nile Virus in Vaccinated and Clinically Affected Horses. Journal of the American Veterinary Medical Association, 226, 240-245. http://dx.doi.org/10.2460/javma.2005.226.240

[140] Bergman, P.J., McKnight, J., Novosad, A., Charney, S., Farrelly, J., Craft, D., Wulderk, M., Jeffers, Y., Sadelain, M., Hohenhaus, A.E., Segal, N., Gregor, P., Engelhorn, M., Riviere, I., Houghton, A.N. and Wolchok, J.D. (2003) LongTerm Survival of Dogs with Advanced Malignant Melanoma after DNA Vaccination with Xenogeneic Human Tyrosinase: A Phase I Trial. Clinical Cancer Research, 9, 1284-1290.

[141] Liao, J.C., Gregor, P., Wolchok, J.D., Orlandi, F., Craft, D., Leung, C., Houghton, A.N. and Bergman, P.J. (2006) Vaccination with Human Tyrosinase DNA Induces Antibody Responses in Dogs with Advanced Melanoma. Cancer Immunity, 6, 8.

[142] Kalams, S.A., Parker, S., Jin, X., Elizaga, M., Metch, B., Wang, M., Hural, J., Lubeck, M., Eldridge, J., Cardinali, M., Blattner, W.A., Sobieszczyk, M., Suriyanon, V., Kalichman, A., Weiner, D.B. and Baden, L.R. (2012) Safety and Immunogenicity of an HIV-1 Gag DNA Vaccine with or without IL-12 and/or IL-15 Plasmid Cytokine Adjuvant in Healthy, HIV-1 Uninfected Adults. PLoS ONE, 7, e29231. http://dx.doi.org/10.1371/journal.pone.0029231

[143] Pereira, V.B., Zurita-Turk, M., Saraiva, T.D.L., Prósperi, C.D.C., Souza, B.M., Mancha-Agreti, P., Lima, F.A., Pfeiffer, V.N., Azevedo, M.S.P., Rocha, C.S., Pontes, D.S., Azevedo, V. and Miyoshi, A. (2013) DNA Vaccines Approach: From Concepts to Applications. Microbial Pathogens and Strategies for Combating Them: Science, Technology and Education. Microbial Book Series, 2013 Edition.

[144] Kutzler, M. and Weiner, D.B. (2008) DNA Vaccines: Ready for Prime Time? Nature, 9, 776-788. 